\title{
Gideon, Miranda, and the Downside of Incorporation ${ }^{*}$
}

\author{
Michael J. Zydney Mannheimer**
}

\begin{abstract}
The United States Supreme Court decisions in Gideon $v$. Wainwright and Miranda $v$. Arizona are cut from the same cloth. Each was the result of the Court's frustration with the tedium of case-by-case analysis, and so each represents a broad, bright-line rule. Gideon dictated that in all serious criminal cases, the defendant is entitled to counsel, ending the muddled, multi-factor analysis of Betts $v$. Brady. Miranda dictated that in all custodial interrogations, the suspect is entitled to counsel and to be informed of that right and his right to remain silent, purporting to settle three decades of lack of clarity in the jurisprudence of coercive interrogations.

And both Gideon and Miranda are widely perceived as failures. Miranda, a contentious 5-4 decision once decried by conservatives as having gone too far, has spawned a jurisprudence widely recognized by liberals as anemic. In the overwhelming majority of cases, warnings are given and a waiver obtained, and courts in such cases are highly unlikely to rule that a confession was coerced irrespective of what occurred following warnings and waiver. Gideon, once a warmly greeted unanimous decision, is now almost uniformly looked upon as representing a promise unfulfilled. In large part, this is a result of Strickland $v$. Washington, whose test to determine whether counsel was constitutionally ineffective prevents courts from disturbing convictions except in the most extreme cases, where counsel's actions can have no conceivable strategic justification.

This Article argues that the perceived failings of these two doctrinal lines spring from the same source: the use of very strong presumptions that sharply constrain judicial discretion. Miranda evolved into a rule establishing a virtually irrebuttable presumption that statements resulting from a custodial interrogation are uncoerced if they are preceded by warnings and waiver. Gideon evolved into a rule

* $\quad{ }^{2} 2014$ Michael J. Zydney Mannheimer.

Professor of Law and Associate Dean for Faculty Development, Salmon P. Chase College of Law, Northern Kentucky University. My thanks to Stephen Henderson, Lea Johnston, Anna Roberts, Larry Rosenthal, and other participants of CrimFest 2014, held at Rutgers School of Law, Newark, for their helpful comments on an earlier version of this Article.
\end{abstract}


establishing a virtually irrebuttable presumption that if the defendant had an attorney, that attorney performed adequately to protect the defendant's rights. As a result of each rule, judges are largely prevented from sifting through the messy facts of individual cases.

This Article further argues that these later developments cannot be explained exclusively in crass political terms, as the result of more conservative Courts cutting back on rights granted by the liberal Warren Court. Rather, they were largely the result of the incorporation agenda of the Warren Court itself. By its nature, incorporation favors brightline rules, as contrasted with the nebulous standards of fundamental fairness analysis. Gideon and Miranda represent two such rules. But bright-line rules typically do not entirely replace nebulous, multifactored standards. Rather, rules often either move standards to other places in the analysis or generate the need for entirely new standards. Thus, multi-factored standards persisted after Gideon and Miranda, in the form of the tests used to determine whether counsel was reasonably effective and whether an interrogation was coercive despite the provision of Miranda warnings. But because the Court had fully bought into incorporation by the end of the Warren Court era, and because incorporation exerts a strong preference for rules over standards, the Court was required to erect further rules to support the structure it had begun to build in the 1960s. These "scaffolding" rules, in the form of the heavy presumptions mentioned above, were advanced by liberal and conservative members of the Court alike.

\section{INTRODUCTION}

We recently celebrated the fiftieth anniversary of the United States Supreme Court decision in Gideon v. Wainwright. ${ }^{1}$ Before we know it, we will be observing the golden anniversary of the decision in Miranda $v$. Arizona. ${ }^{2}$ These two landmarks of the Warren Court ${ }^{3}$ are rarely discussed together. This is surprising, as they are cut from the same cloth. Each was the result of the Court's frustration with the tedium of case-by-case analysis, and so each represents a bright-line rule. Gideon dictated that in all serious criminal cases, the defendant is entitled to counsel, ending the confusing and unpredictable analysis required by Betts $v$. Brady. ${ }^{4}$ Miranda dictated that the products of custodial interrogations will be

372 U.S. 335 (1963).

384 U.S. 436 (1966).

Donald A. Dripps, Why Gideon Failed: Politics and Feedback Loops in the Reform of Criminal Justice, 70 WASH. \& LEE L. REV. 883, 884 n.1 (2013) (characterizing Gideon and Miranda as "landmarks in criminal law").

$4 \quad 316$ U.S. 455, 456-57 (1942). 
admissible only if the suspect is first informed of his rights to silence and counsel, and if he waives those rights, purporting to settle three decades of muddled jurisprudence in the law of coercive interrogations.

And both Gideon and Miranda are widely perceived as failures. Miranda, a contentious 5-4 decision once bemoaned by conservatives as having gone too far, has evolved into a jurisprudence widely recognized by liberals as not having gone far enough. In particular, because the overwhelming majority of criminal defendants waive their Miranda rights, and because the provision of these warnings is regarded as "a virtual ticket of admissibility," "what was initially conceived of as a roadblock to coercive police tactics has been transformed into little more than a speed bump. Gideon, once a warmly greeted unanimous decision, is now almost uniformly looked upon as having been severely undercut by later developments. Though several culprits can be blamed for Gideon's perceived demise, a prime suspect is the Court's decision in Strickland $v$. Washington, ${ }^{6}$ which erects a virtually irrebuttable presumption that any warm body with a law degree sitting next to the defendant during trial has provided effective assistance of counsel.

This Article makes two arguments. First, it claims that the perceived failings of Gideon and Miranda spring from the same source: a heavy presumption that constrains judicial discretion by preventing judges from looking too closely at the facts of individual cases. Gideon evolved into a rule establishing the presumption of attorney competence, a virtually irrebuttable presumption that if the defendant had an attorney, that attorney performed adequately to protect the defendant's rights. Miranda evolved into a rule establishing the presumption of non-coercion, a virtually irrebuttable presumption that statements resulting from a custodial interrogation are uncoerced if they are preceded by Miranda warnings and waiver.

Second, this Article argues that the conventional account of the evolution of Gideon and Miranda in crass political terms - as the results of the conservative backlash of the Burger and Rehnquist Courts against the progressivism of the Warren Court - is incomplete. The trajectory of both Gideon and Miranda, both upward and downward, cannot be understood divorced from the push toward incorporation of the Bill of Rights. It was this push that led the Court to generally eschew nebulous, multi-factored standards in favor of bright-line rules. And it was this push that ultimately led the Court to employ the prosecution-friendly presumptions discussed above. For once the Court created the bright-line Gideon and Miranda rules, the indeterminate standards those rules supposedly displaced did not disappear. Rather, they simply moved from one part of the analysis to another (in the case of Miranda) or changed in form (in the case of Gideon). Provision of counsel through Gideon's bright-line rule simply triggered a multifactored standard as to whether counsel was effective. And compliance with the

\footnotetext{
Missouri v. Seibert, 542 U.S. 600, 608-09 (2004) (plurality opinion).
}

466 U.S. 668 (1984). 
warnings-and-waiver protocol of Miranda's bright-line rule simply returned custodial interrogation to the status quo ante, with courts determining the question of coercion using the same old due process voluntariness test the Court thought it was replacing in Miranda. But because the Court had already rejected the nebulous, standard-like fundamental fairness approach in favor of the more determinate, rule-like incorporation approach, further refinement had to take the form of additional rules, not standards. Once standards were replaced by rules, the Supreme Court needed to provide lower courts with guidance, in the form of these discretion-minimizing presumptions, lest they fall back into the morass of the caseby-case adjudication that was the hallmark of due process methodology prior to the incorporation revolution. Seen in this way, the presumptions of competence and of non-coercion were as much the result of the Warren Court's incorporation project itself as they were the product of conservative backlash.

Part II of this Article describes the groundbreaking decisions in Gideon and Miranda and the messy jurisprudence each decision displaced. Part III sketches the path of each jurisdictional line as it evolved into what many regard as an anemic rule that has failed to live up to its promise. This Part looks at the presumptions established by each doctrinal line which largely constrain judges from honestly confronting arguably coercive police tactics and incompetent lawyering. Part IV explains this shared aspect of the Gideon and Miranda lines as the result of the Warren Court's project to incorporate the Bill of Rights through the Fourteenth Amendment. Once the incorporationist Court had conclusively replaced nebulous standards with bright-line rules, there was little room for caseand fact-specific determinations whether due process had been afforded in individual cases. Instead, the Gideon and Miranda rules had to be "scaffolded" by additional rules that were largely insensitive to case-specific facts.

\section{GIDEON, MIRANDA, AND THE ROAD TO INCORPORATION}

The tale is a familiar one. Out of a deep respect for the values of federalism undergirding our constitutional system, the Supreme Court for most of its history was reluctant to impose hard-and-fast rules on the States to implement the Fourteenth Amendment's command that the States not deprive persons of "life, liberty, or property without due process of law."7 On the other hand, to ignore the paltry nature of what was sometimes deemed by the States to be "due process" would have amounted to abandonment of the judicial role. Instead, the Court took a middle approach, holding the States to a nebulous "fundamental fairness" standard that looked to multiple factors, all relevant but none dispositive, to determine whether due process had been afforded.

That project, most would agree, was a failure. The lack of hard rules wrought a lack of consistency among lower courts. Worse, the standards were so malleable

7 U.S. CONST. amend. XIV, § 1. 
as to be easily manipulated to get to the desired outcome. And in a legal system that relies upon predictability of outcomes to guide behavior, the fuzzy standards of "fundamental fairness" resulted only in uncertainty. So the nebulous standards were replaced by bright-line rules. Thus did the Court take the long road from the "fundamental fairness" approach to the Fourteenth Amendment to the "incorporation" approach.

\section{A. From Fundamental Fairness to Incorporation}

The Supreme Court held long ago that the Bill of Rights applies only to the federal government. ${ }^{8}$ Yet after the Fourteenth Amendment was ratified in 1868, the States were forbidden from depriving "any person of life, liberty, or property without due process of law." 9 Thus, the questions for state criminal procedure became what "due process of law" required and, more specifically, whether and to what extent it applied the provisions of the Bill of Rights to the States. The Court began the twentieth century by requiring that States obey an amorphous "fundamental fairness" standard that encompassed some, but not all, of the same principles embodied in the Bill. By the end of the Warren Court era in 1969, the Court had reversed course and embraced the incorporation of virtually all of the provisions of the Bill of Rights into the Due Process Clause, thus making them applicable against the States.

The paradigmatic description of the Court's practice of imputing to the Due Process Clause only those protections associated with "fundamental fairness" can be found in the Court's decision in Palko v. Connecticut. ${ }^{10}$ The specific question presented there was whether the Fifth Amendment's Double Jeopardy Clause ${ }^{11}$ applied to the States via the Due Process Clause of the Fourteenth Amendment. In rejecting the petitioner's claim that it did, the Court described the restrictions imposed by the Due Process Clause in these narrow terms: it encompassed only "the specific pledges of particular amendments [that] have been found to be implicit in the concept of ordered liberty,"12 those "so rooted in the traditions and conscience of our people as to be ranked as fundamental," ${ }^{13}$ those without which "neither liberty nor justice would exist." In its prior cases, the Court had included within that narrow category the rights to freedom of speech ${ }^{15}$ and of the

\footnotetext{
See, e.g., Barron v. Baltimore, 32 U.S. (7 Pet.) 243, 247 (1833).

"No State shall ... deprive any person of life, liberty, or property without due process of law ...." U.S. CONST. amend. XIV, § 1.

10302 U.S. 319 (1937), overruled by Benton v. Maryland, 395 U.S. 784 (1969).

11 "No person shall . . . be subject for the same offence to be twice put in jeopardy of life or limb ...." U.S. CONST. amend. V.

Palko, 302 U.S. at 324-25.

Id. at 325 (quoting Snyder v. Massachusetts, 291 U.S. 97, 105 (1934)).

Id. at 326.

15 See id. at 324.
} 
press ${ }^{16}$ and the rights to the free exercise of religion ${ }^{17}$ and to peaceable assembly. ${ }^{18}$ However, the Court had excluded many of the criminal procedure provisions of the Bill of Rights, such as the right to be indicted by a grand jury, ${ }^{19}$ the privilege against self-incrimination, ${ }^{20}$ the right to be free of unreasonable searches and seizures, ${ }^{21}$ and the right to confront one's accusers at trial. ${ }^{22}$

By 1947, only a decade after Palko, the Court was sharply split over whether to retain this "fundamental fairness" approach to due process. In Adamson $v$. California, the issue was whether the Due Process Clause of the Fourteenth Amendment was violated by a California law allowing the court and prosecutor to comment on the defendant's decision not to testify at his trial. ${ }^{23}$ The Court, reaffirming its 1908 decision in Twining $v$. New Jersey, ${ }^{24}$ held that the SelfIncrimination Clause of the Fifth Amendment ${ }^{25}$ did not apply to the States because "[t]he due process clause of the Fourteenth Amendment . . . does not draw all the rights of the federal Bill of Rights under its protection. $" 26$

But Justice Black, who had signed onto the Palko decision shortly after having joined the Court, ${ }^{27}$ had by this time acquired a different viewpoint. Joined by Justice Douglas, he asserted that the Due Process Clause of the Fourteenth Amendment incorporated the entire Bill of Rights and only the Bill of Rights. ${ }^{28} \mathrm{He}$ defended this position largely on grounds of judicial restraint: keying the constraints that applied to the States to the provisions of the Bill of Rights kept judges from going at large with few guideposts in determining what incidents of the criminal process are required to render it "fundamentally fair." 29 Justice Murphy, joined by Justice Rutledge, filed a brief dissent agreeing with Justice Black "that the specific guarantees of the Bill of Rights should be carried over

6 See id.

See id.

See id.

See Hurtado v. California, 110 U.S. 516, 520-21 (1884).

20 See Twining v. New Jersey, 211 U.S. 78, 106, 111-12 (1908), overruled by Malloy v. Hogan, 378 U.S. 1, 7 (1964).

21 See Weeks v. United States, 232 U.S. 383, 398 (1914).

22 See West v. Louisiana, 194 U.S. 258, 261-62 (1904), overruled by Pointer v. Texas, 380 U.S. 400, 406 (1965).

23332 U.S. 46, 48-49 (1947), overruled by Griffin v. California, 380 U.S. 609, 619 (1965).

24211 U.S. 78 at 106, 111-112.

25 "No person shall . . . be compelled in any criminal case to be a witness against himself ...." U.S. CONST. amend. V.

26 Adamson, 332 U.S. at 53.

27 See Michael J.Z. Mannheimer, Coerced Confessions and the Fourth Amendment, 30 HASTINGS CONST. L.Q. 57, 79 n.139 (2002).

28 See Adamson, 332 U.S. at 69-92 (Black, J., dissenting).

29 See id. at 69 ("This decision reasserts a constitutional theory ... that this Court is endowed by the Constitution with boundless power under 'natural law' periodically to expand and contract constitutional standards to conform to the Court's conception of what at a particular time constitutes 'civilized decency' and 'fundamental principles of liberty and justice.'”). 
intact into the ... Fourteenth Amendment." 30 He differed with Justice Black only insofar as Justice Murphy believed that the Due Process Clause of the Fourteenth Amendment did not encompass only the rights included in the Bill of Rights. ${ }^{31}$

Justice Frankfurter responded in a lengthy concurring opinion, defending the "fundamental fairness" regime. He wrote: "The [Fourteenth] Amendment neither comprehends the specific provisions by which the founders deemed it appropriate to restrict the federal government nor is it confined to them.",32 Justice Frankfurter justified his position with reference to the text and legislative history of the Amendment. He pointed out that it is difficult to read the text of the Due Process Clause as a stand-in for the entirety of the Bill of Rights. ${ }^{33}$ Moreover, Justice Frankfurter claimed that there was little evidence that those who framed and ratified the Fourteenth Amendment believed they were imposing the Bill of Rights on the States. ${ }^{34}$

Adamson and, in particular, the Frankfurter concurrence appeared to entrench the "fundamental fairness" approach. In retrospect, however, Adamson represents the zenith of the fundamental fairness regime. Four Justices rejected it in favor of strict incorporation; one more vote would mean the end of the "fundamental fairness" methodology. In short order, that fifth vote appeared, along with several others for good measure. In the span of only two decades, as Chief Justice Warren was poised to leave the Court, "fundamental fairness" was essentially dead. As the Court wrote in Duncan v. Louisiana:

[T]he Due Process Clause of the Fourteenth Amendment. . . . now protects the right to compensation for property taken by the State; the rights of speech, press, and religion covered by the First Amendment; the Fourth Amendment rights to be free from unreasonable searches and seizures and to have excluded from criminal trials any evidence illegally seized; the right guaranteed by the Fifth Amendment to be free of

30 Id. at 124 (Murphy, J., dissenting).

1 Justice Murphy wrote:

I am not prepared to say that the [Fourteenth Amendment] is entirely and necessarily limited by the Bill of Rights. Occasions may arise where a proceeding falls so far short of conforming to fundamental standards of procedure as to warrant constitutional condemnation in terms of a lack of due process despite the absence of a specific provision in the Bill of Rights.

Id. (Murphy, J., dissenting). I have in the past differentiated between Justice Black's and Justice Murphy's positions, calling the former "total, exclusive incorporation" and the latter "total, nonexclusive" incorporation. See Mannheimer, supra note 27, at 79.

32 Adamson, 332 U.S. at 66 (Frankfurter, J., concurring).

33 See id. at 63 ("It would be extraordinarily strange for a Constitution to convey such specific commands in such a roundabout and inexplicit way.").

34 See id.at 64 ("It could hardly have occurred to these States that by ratifying the Amendment they uprooted their established methods for prosecuting crime and fastened upon themselves a new prosecutorial system."). 
compelled self-incrimination; and the Sixth Amendment rights to counsel, to a speedy and public trial, to confrontation of opposing witnesses, and to compulsory process for obtaining witnesses. ${ }^{35}$

And these provisions apply to the States in the exact same way they apply to the federal government. ${ }^{36}$

The route from fundamental fairness to full-on incorporation provides the framework for the two paths with which this Article is concerned: from a spotty and inconsistent right to appointed counsel in state court to Gideon's promise of appointed counsel in every serious criminal case; and from a nebulous right to be free from some uncertain amount of psychological pressure in the interrogation room to Miranda's protocol of warnings and waiver in every case to dispel the inherent compulsion of interrogations.

\section{B. From Powell to Gideon}

The road to Gideon began with Powell v. Alabama. ${ }^{37}$ In that case, known colloquially as the "Scottsboro Boys" case, ${ }^{38}$ nine African-American youths had been accused of raping two young white women on a train traveling through Alabama. ${ }^{39}$ The defendants were ignorant, illiterate, and residents of other States. ${ }^{40}$ As one might imagine, given the place, time, and nature of the accusations, "the proceedings, from beginning to end, took place in an atmosphere of tense, hostile, and excited public sentiment," and the defendants were kept under armed guard for their own safety. ${ }^{41}$

The defendants were never asked if they wanted to attempt to secure counsel on their behalf or allowed the opportunity to communicate with family or friends who might do so for them. ${ }^{42}$ Instead, the trial judge appointed all the members of

35391 U.S. 145, 148 (1968) (footnotes omitted).

36 See Henry J. Friendly, The Bill of Rights as a Code of Criminal Procedure, 53 CAL. L. REV. 929, 935 (1965) ("[T] he theory continues that once a particular provision of the Bill of Rights makes the grade for 'absorption,' it comes over to the states with all the overlays the Court has developed in applying it to the Federal Government ...."). The only exception appears to be the jury-trial requirement of the Sixth Amendment, which arguably requires twelve-person juries and unanimous guilty verdicts in federal court but not in state court. See Apodaca v. Oregon, 406 U.S. 356, 373-77 (1972) (Powell, J., concurring in the judgment) (providing fifth vote in support of judgment and opining that unanimity is required by Sixth but not Fourteenth Amendment); Williams v. Florida, 399 U.S. 78, 86-103 (1970) (holding that twelve-person juries are not required by Fourteenth Amendment, without deciding whether they are required by the Sixth Amendment).

$37 \quad 287$ U.S. 45 (1932).

38 See, e.g., Michael Klarman, The Racial Origins of Modern Criminal Procedure, 99 MicH. L. REV. 48, 51 (2000).

39 See Powell, 287 U.S. at 49, 51.

40 See id. at 52.

41 Id. at 51.

42 See id. at 52. 
the local bar to represent the defendants jointly at their arraignment, and assumed that these counsel would continue to represent them at trial, which began six days later. ${ }^{43}$ At trial, the defendants in Powell were convicted and sentenced to death. ${ }^{44}$

The Supreme Court reversed on the ground that the proceedings had violated the defendants' Fourteenth Amendment right not to be deprived of life without due process of law. Because the defendants essentially lacked counsel during the critical pre-trial period, the issue was whether they had a federal constitutional right to counsel at that time. Incanting the language of the ascendant fundamental fairness regime, the Court framed the issue as whether "the right involved is of such a character that it cannot be denied without violating those 'fundamental principles of liberty and justice which lie at the base of all our civil and political institutions." "45 The Court held that the right to retain counsel during this period was protected by the Due Process Clause: "The right to be heard would be, in many cases, of little avail if it did not comprehend the right to be heard by counsel. ${ }^{46}$

Importantly, the Court went even further. Not only was the right to retain counsel an aspect of due process, but, under the circumstances, failure to appoint counsel for defendants unable to retain their own counsel would violate the Due Process Clause of the Fourteenth Amendment as well. ${ }^{47}$ But the perfunctory appointment of the entire local bar during that period "even if made for all purposes" would not have sufficed. ${ }^{48}$ The undifferentiated appointment of every member of the local bar to represent them left the defendants without a single advocate charged with zealously representing their interests, and instead diluted that responsibility, leaving no particular attorney accountable to them. ${ }^{49}$ The Court

43 See id.at 50, 53, 56.

44 See id.at 50.

45 See id. at 67 (quoting Hebert v. Louisiana, 272 U.S. 312, 316 (1927)).

46 Id. at 68-69.

47 See $i d$. at 71 ("[U]nder the circumstances . . . the necessity of counsel was so vital and imperative that the failure of the trial court to make an effective appointment of counsel was likewise a denial of due process within the meaning of the Fourteenth Amendment.").

$48 \quad I d$. at 56.

49 See id. (" $[\mathrm{I}] \mathrm{n}$ the very nature of things ... they would not, thus collectively named, have been given that clear appreciation of responsibility or impressed with that individual sense of duty which should and naturally would accompany the appointment of a selected member of the bar, specifically named and assigned."). The Court's intuition is supported by modern research on individual and group responsibility, the classic exposition being BIBB LATANÉ \& JOHN M. DARLEY, The UnResponsive Bystander: Why Doesn't He Help? (1970). Joint appointment of attorneys to represent the entire group of defendants simultaneously might have violated another norm associated with modern right-to-counsel rules: the right to un-conflicted counsel. Because the seven defendants were alleged to be accomplices in the same incident, some might have defended by claiming that others in the group, but not they, had perpetrated the crime. Under those circumstances, an attorney representing all the defendants would have had an intractable conflict of interest. See Holloway v. Arkansas, 435 U.S. 475, 484 (1978). 
left open the question of how far this right of appointed counsel extended. ${ }^{50}$ Indeed, the Court narrowly circumscribed the new rule it was propounding:

All that it is necessary now to decide, as we do decide, is that in a capital case, where the defendant is unable to employ counsel, and is incapable adequately of making his own defense because of ignorance, feeblemindedness, illiteracy, or the like, it is the duty of the court . . . to assign counsel for him as a necessary requisite of due process of law ... ${ }^{51}$

Accordingly, not only was this latter portion of the Powell opinion dicta-the Court had already decided that the defendants' Fourteenth Amendment rights had been violated because they had not been given adequate opportunity to secure counsel $^{52}$ - but it was narrowly delineated dicta to boot. ${ }^{53}$ Nevertheless, Powell came to stand for the proposition that due process required appointment of counsel for an indigent state defendant in any capital case. ${ }^{54}$ The question remained whether and to what extent the Fourteenth Amendment required the appointment of counsel in non-capital cases as well.

Ten years later, in Betts v. Brady, ${ }^{55}$ the Court squarely rejected the claim that the appointment of counsel was required by the Due Process Clause in all felony cases. Betts, charged with robbery in Maryland state court and unable to afford counsel, unsuccessfully requested that counsel be appointed to represent him. ${ }^{56}$ After representing himself, he was found guilty and sentenced to eight years in prison. $^{57}$ On appeal to the Supreme Court, he argued that the Fourteenth Amendment required the appointment of counsel in every case where the

50 See Powell, 287 U.S. at 71 ("Whether this would be so in other criminal prosecutions, or under other circumstances, we need not determine.").

51 Id.

52 See id. at 76 (Butler, J., dissenting) ("If correct, the ruling that the failure of the trial court to give petitioners time and opportunity to secure counsel was a denial of due process is enough, and with this the opinion should end.").

53 See Gideon v. Wainwright, 372 U.S. 335, 350 (1963) (Harlan, J., concurring) ("[T]hese limiting facts were not added to the opinion as an afterthought; they were repeatedly emphasized, and were clearly regarded as important to the result.") (citation omitted).

54 See, e.g., Bute v. Illinois, 333 U.S. 640, 676 (1948) ("[T]his Court repeatedly has held that failure to appoint counsel to assist a defendant or to give a fair opportunity to the defendant's counsel to assist him in his defense where charged with a capital crime is a violation of due process of law under the Fourteenth Amendment."); see also Gideon, 372 U.S. at 347 (Clark, J., concurring in the judgment) (observing that prior to Bute, there was "no language in any cases in th[e] Court indicating that appointment of counsel in all capital cases was required by the Fourteenth Amendment.").

55316 U.S. 455 (1942).

$56 \quad I d$. at 456-57.

57 See id. at 457. 
defendant is too poor to afford counsel. ${ }^{58}$ Only four years earlier, in Johnson $v$. Zerbst, the Court had held that the Assistance of Counsel Clause of the Sixth Amendment ${ }^{59}$ requires as much in federal cases. ${ }^{60}$ But the Betts Court rejected the notion that the Fourteenth Amendment contained the identical requirement. ${ }^{61}$ The Court wrote that due process is "less rigid and more fluid" than the provisions of the Bill of Rights, and "less a matter of rule." 62 Echoing Palko, it wrote that whether state action "constitute[d] a denial of fundamental fairness, shocking to the universal sense of justice," depended on the totality of facts of each case. ${ }^{63}$ And pointing to the relative simplicity of the factual issues of Betts' robbery case, as well as the fact that Betts was "forty-three years old, of ordinary intelligence," and had previous experience in the criminal justice system, the Court concluded that he had not been deprived of liberty without due process. ${ }^{64}$

Although Betts itself did not use the term, it came to be understood as holding that there was a constitutional obligation on the part of a State to appoint counsel in a criminal case only where there were "special circumstances." 65 As Powell

58 See id. at 462 ("The petitioner ... asks us, in effect, to apply a rule ... . that, in every case, whatever the circumstances, one charged with a crime, who is unable to obtain counsel, must be furnished counsel by the state.").

59 "In all criminal prosecutions, the accused shall enjoy the right . . . to have the Assistance of Counsel for his defense." U.S. CONST. amend. VI.

60304 U.S. 458, 463 (1938) ("The Sixth Amendment withholds from federal courts, in all criminal proceedings, the power and authority to deprive an accused of his life or liberty unless he has or waives the assistance of counsel.").

61 See Betts, 316 U.S. at 461-62 ("The due process clause of the Fourteenth Amendment does not incorporate, as such, the specific guarantees found in the Sixth Amendment . ..."); see also Bute v. Illinois, 333 U.S. 640, 675 (1948) ("[T]he Fourteenth Amendment does not . . have the effect of requiring the several states to conform the procedure of their state criminal trials to the precise procedure of the federal courts ....").

62 Betts, 316 U.S. at 462.

63 Id.; see also Gibbs v. Burke, 337 U.S. 773, 781 (1949) ("The due process clause is not susceptible to reduction to a mathematical formula."); Bute, 333 U.S. at 649 ("[D]ue process . . . has reference . . . to a standard of process that may cover many varieties of processes that are expressive of differing combinations of historical or modern, local or other juridical standards, provided they do not conflict with the "fundamental principles of liberty and justice which lie at the base of all our civil and political institutions."' (quoting Hebert v. Louisiana, 272 U.S. 312, 316 (1929))).

64 Betts, 316 U.S. at 472-73.

65 See, e.g., Gideon v. Wainwright, 372 U.S. 335, 350 (1963) (Harlan, J., concurring) (describing Betts as having "admit[ted] of the possible existence of special circumstances in noncapital as well as capital trials, while at the same time insisting that such circumstances be shown in order to establish a denial of due process."); Palmer v. Ashe, 342 U.S. 134, 135 (1951) (“[T]he Due Process Clause of the Fourteenth Amendment requires states to afford defendants assistance of counsel in non-capital criminal cases when there are special circumstances showing that without a lawyer a defendant could not have an adequate and fair defense."); Bute, 333 U.S. at 677 ("In a noncapital state felony case, this Court has recognized the constitutional right of the accused to the assistance of counsel for his defense when there are special circumstances showing that, otherwise, the defendant would not enjoy that fair notice and adequate hearing which constitute the foundation of due process of law in the trial of any criminal charge."). 
came to be understood, capital charges constituted special circumstances in themselves. In non-capital cases, the Court looked to such factors as "the gravity of the crime[,] . . . the age and education of the defendant, the conduct of the court or the prosecuting officials, and the complicated nature of the offense charged and the possible defenses thereto . . . "66 Thus, "special circumstances" fell into two general categories: those relating to the charges against the defendant, and those relating to the characteristics of the defendant himself.

Over the course of the next twenty years, the Court decided at least twenty cases, an average of one per term, presenting the issue whether there were "special circumstances" requiring appointment of counsel. ${ }^{67}$ In a significant number of cases, in finding a due process violation, the Court relied on multiple factors without putting exclusive weight on one in particular. ${ }^{68}$ In Carnley v. Cochran, for example, the Court pointed to both the complexity of the statutory scheme, by which "two sets of Florida criminal statutes" arguably criminalized the defendant's acts, and the fact that the defendant was illiterate. ${ }^{69}$ In Moore v. Michigan, the Court relied on the fact that the defendant was seventeen years old, had a seventhgrade education, was charged with murder, and had several potentially full or partial defenses. ${ }^{70}$ And in McNeal v. Culver, the Court relied on an amalgam of defendant-specific facts, such as his mental illness, lack of education, and unfamiliarity with the criminal process, on the one hand, and trial-specific facts, such as the complexity of the Florida law of assault and the admissibility of the defendant's confession on the other. ${ }^{71}$

66 Uveges v. Pennsylvania, 335 U.S. 437, 441 (1948).

67 See Carnley v. Cochran, 369 U.S. 506 (1962); Chewning v. Cunningham, 368 U.S. 443 (1962); McNeal v. Culver, 365 U.S. 109 (1961); Hudson v. North Carolina, 363 U.S. 697 (1960); Cash v. Culver, 358 U.S. 633 (1959); Moore v. Michigan, 355 U.S. 155 (1957); Massey v. Moore, 348 U.S. 105 (1954); Palmer, 342 U.S. 134; Quicksall v. Michigan, 339 U.S. 660 (1950); Gibbs v. Burke, 337 U.S. 773 (1949); Uveges, 335 U.S. 437; Wade v. Mayo, 334 U.S. 672 (1948); Gryger v. Burke, 334 U.S. 728 (1948); Townsend v. Burke, 334 U.S. 736 (1948); Bute v. Illinois, 333 U.S. 640 (1948); Marino v. Ragen, 332 U.S. 561 (1947); De Meerleer v. Michigan, 329 U.S. 663 (1947); Rice v. Olson, 324 U.S. 786 (1945); Tomkins v. Missouri, 323 U.S. 485 (1945); Williams v. Kaiser, 323 U.S. 471 (1945).

68 In a number of cases, the Court relied primarily on the age and inexperience of the defendant, coupled with particularly grave crimes punished by life in prison. See Uveges, 335 U.S. at 442 ("Petitioner was [seventeen years old] and inexperienced in the intricacies of criminal procedure when he pleaded guilty to crimes which carried a maximum sentence of eighty years."); Marino, 332 U.S. at 562 (State confessed error where defendant was eighteen years old, had been in country for only two years, did not speak English, pled guilty to murder, and was sentenced to life imprisonment); De Meerleer, 329 U.S. at 664-65 (finding due process violation where uncounseled seventeen year-old was convicted of first-degree murder and sentenced to life imprisonment); see also Wade, 334 U.S. at 683 (heavily deferring to federal district court's factual finding "that Wade was an inexperienced youth incapable of adequately representing himself" on a charge carrying five years in prison).

69 Carnley, 369 U.S. at 507-10, 511.

70 Moore, 355 U.S. at 159-60.

71 McNeal, 365 U.S. at 112. 
Meanwhile, a number of Justices continued to press their claim that the Due Process Clause of the Fourteenth Amendment incorporated the Bill of Rights part and parcel. ${ }^{72}$ They attacked the "vague, fickle standard" of Betts, which "ha[d] served not to guide but to confuse the courts" by imposing "the perplexing responsibility of appointing lawyers for an accused when a trial judge believes that a failure to do so would be "shocking to the universal sense of justice.",73

Finally, in 1963, amidst the Warren Court's incorporation revolution, the other shoe dropped. Only a year earlier, the Court had held that the Eighth Amendment's bar on "cruel and unusual punishments" 74 applies to the States by dint of the Fourteenth Amendment. ${ }^{75}$ And the year before that, the Court had incorporated the Fourth Amendment rule that illegally seized evidence must be excluded from the prosecutor's case-in-chief at trial. ${ }^{76}$ Now, in Gideon $v$. Wainwright, the Court overruled Betts and unanimously held that the Sixth Amendment's Assistance of Counsel Clause applied to the States via the Fourteenth Amendment as well. ${ }^{77}$ The court reasoned that, in any criminal case, "any person haled into court, who is too poor to hire a lawyer, cannot be assured a fair trial unless counsel is provided for him."78 In effect, as Justice Harlan put it in his concurrence, the Court "c[a]me to recognize . . . that the mere existence of a serious criminal charge constituted in itself special circumstances requiring the services of counsel at trial." ${ }^{, 79}$

\section{From Brown to Miranda}

72 See, e.g., Carnley, 369 U.S. at 518 (Black, J., joined by Warren, C.J., and Douglas, J., concurring) (reiterating the "belief that the Fourteenth Amendment makes applicable to the States the Sixth Amendment's guarantee that 'In all criminal prosecutions, the accused shall . . . have the Assistance of Counsel for his defense." (alteration in original)); McNeal, 365 U.S. at 119 (Douglas, J., joined by Brennan, J., concurring) ("Betts v. Brady . . should be overruled."); Gibbs, 337 U.S. at 782 ("Mr. Justice BLACK and Mr. Justice DOUGLAS . . . think that Betts v. Brady should be overruled."); Uveges, 335 U.S. at 440 ("Some members of the Court think that where serious offenses are charged, failure of a court to offer counsel in state criminal trials deprives an accused of rights under the Fourteenth Amendment."); Bute, 333 U.S. at 678 (Douglas, J., joined by Black, Murphy, and Rutledge, JJ., dissenting) ("[A] chief purpose of the Fourteenth Amendment was to protect the safeguards of the Bill of Rights against invasion by the states.").

73 See, e.g., Carnley, 369 U.S. at 518-19 (Black, J., joined by Warren, C.J., and Douglas, J., concurring).

74 See U.S. CONST. amend. VIII ("Excessive bail shall not be required, nor excessive fines imposed, nor cruel and unusual punishments inflicted.").

75 See Robinson v. California, 370 U.S. 660, 667 (1962).

76 See Mapp v. Ohio, 367 U.S. 643, 660 (1961).

77372 U.S. 335, 342 (1963) (determining that "the Court in Betts was wrong . . . in concluding that the Sixth Amendment's guarantee of counsel is not one of the[] fundamental rights" protected by the Fourteenth Amendment).

78 Id. at 344.

79 Id. at 351 (Harlan, J., concurring). 
Miranda shares many similarities with Gideon. Like Gideon, Miranda's roots are in the heavily racialized criminal justice system of the Deep South in the 1930s. Like Gideon, the road to Miranda was marked with fits and starts as the Court struggled to apply a nebulous, multi-factored standard that looked to both the objective circumstances and the characteristics of the individual. And as in Gideon, the Miranda Court finally sought to cure the drawbacks of this standard by imposing a bright-line rule.

The Supreme Court began regulating coercive interrogation tactics by state officials in 1936 in Brown v. Mississippi. ${ }^{80}$ In that case, three black sharecroppers were suspected of murdering their white landlord. ${ }^{81}$ The three confessed to the crimes only after having been severely whipped and told that the whipping would continue until they confessed. ${ }^{82}$ Their confessions were admitted into evidence against them at their trial for murder and constituted the only evidence of their guilt. $^{83}$

On appeal to the Supreme Court, the State of Mississippi reminded the Court that it had held in Twining $v$. New Jersey nearly thirty years earlier that the SelfIncrimination Clause did not apply to the States via the Due Process Clause of the Fourteenth Amendment. ${ }^{84}$ The Court responded that

[T] he question of the right . . . to withdraw the privilege against selfincrimination is not here involved. The compulsion to which [Twining] refer[red] is that of the processes of justice by which the accused may be called as a witness and required to testify. Compulsion by torture to extort a confession is a different matter. ${ }^{85}$

Invoking the "fundamental fairness" standard, the Court wrote that a State could withdraw the privilege but it could not " offend[] some principle of justice so rooted in the traditions and conscience of our people as to be ranked as fundamental." sense of justice," and constituted "a wrong so fundamental that [they] made the whole proceeding a mere pretense of a trial and rendered the conviction and sentence wholly void." ${ }^{, 7}$ Brown thus stands for the proposition that where a conviction is procured through a confession of the defendant obtained by physical violence, the defendant has been deprived of life, liberty, or property without due

80297 U.S. 278 (1936).

81 See id. Although the races of the parties are not clear from the Court's opinion, they are identified in other sources. See, e.g., Klarman, supra note 38, at 51.

82 Brown, 297 U.S. at 281-82.

83 Id. at $279,283$.

84211 U.S. 78 (1908), overruled by Malloy v. Hogan, 378 U.S. 1, 7 (1964).

85 Brown, 297 U.S. at 285.

86 Id. (quoting Snyder v. Massachusetts, 291 U.S. 97, 105 (1905) (alteration added)).

87 Id. at 286 
process of law in violation of the Fourteenth Amendment. ${ }^{88}$

The Court soon extended Brown to rule that confessions obtained through psychological coercion rather than physical force also could not be used to obtain a criminal conviction. The Court famously wrote in Blackburn v. Alabama:

[C]oercion can be mental as well as physical, and ... the blood of the accused is not the hallmark of an unconstitutional inquisition .... [T]he efficiency of the rack and the thumbscrew can be matched, given the proper subject, by more sophisticated modes of 'persuasion.' A prolonged interrogation of an accused who is ignorant of his rights and who has been cut off from the moral support of friends and relatives is not infrequently an effective technique of terror. ${ }^{89}$

The question in every case was whether the confession was truly the product of the suspect's free will or if, instead, his or her free will had been "overborne." 90

The Court was capable of articulating the standard in the simplest of terms: "The limits in any case depend upon a weighing of the circumstances of pressure against the power of resistance of the person confessing." 91 The simplicity was deceptive. As with the due process right-to-counsel inquiry, the due process coerced confession inquiry looked to two categories of factors. First, the Court looked to the objective circumstances of the interrogation itself, such as the length and persistence of the questioning, ${ }^{92}$ any deprivation of sleep ${ }^{93}$ or food, ${ }^{94}$ any humiliating treatment of the suspect at the hands of the police, ${ }^{95}$ the holding of the

88 Id. at 285-86; accord Stein v. New York, 346 U.S. 156, 182 (1953) ("Physical violence or threat of it by the custodian of a prisoner during detention serves no lawful purpose, invalidates confessions that otherwise would be convincing, and is universally condemned by the law."), overruled by Jackson v. Denno, 378 U.S. 368 (1964).

89361 U.S. 199, 206 (1960) (footnote omitted). See also Jackson, 378 U.S. at 389 ("[P]olice conduct requiring exclusion of a confession has evolved from acts of clear physical brutality to more refined and subtle methods of overcoming a defendant's will."); Townsend v. Sain, 372 U.S. 293, 307 (1963) ("These standards are applicable whether a confession is the product of physical intimidation or psychological pressure ....").

90 Reck v. Pate, 367 U.S. 433, 440 (1961); see also Blackburn, 361 U.S. at 208 (question was whether the confession was "the product of a rational intellect and a free will").

91 Stein, 346 U.S. at 185.

92 See Clewis v. Texas, 386 U.S. 707, 709, 711-12 (1967); Davis v. North Carolina, 384 U.S. 737, 739, 746-47, 752 (1966); Gallegos v. Colorado, 370 U.S. 49, 52, 55 (1962).

93 See Greenwald v. Wisconsin, 390 U.S. 519, 520-21 (1968); Clewis, 386 U.S. at 709, 712; Culombe v. Connecticut, 367 U.S. 568, 622 (1961) (plurality); Leyra v. Denno, 347 U.S. 556, 55960 (1954); Stein, 346 U.S. at 185; Watts v. Indiana, 338 U.S. 49, 53 (1949) (plurality); Ashcraft v. Tennessee, 322 U.S. 143,153 (1940).

94 See Greenwald, 390 U.S. at 521; Clewis, 386 U.S. at 709-10, 712; Davis, 384 U.S. at 746; Culombe, 367 U.S. at 622 (plurality); Reck, 367 U.S. at 441; Payne v. Arkansas, 356 U.S. 560, 567 (1958).

95 See Culombe, 367 U.S. at 622 (plurality); Malinski v. New York, 324 U.S. 401, 405 (1945). 
suspect incommunicado ${ }^{96}$ (particularly in foreign surroundings), ${ }^{97}$ whether the suspect was advised of his rights ${ }^{98}$ or taken before a magistrate, ${ }^{99}$ whether the suspect ever requested counsel, ${ }^{100}$ any potential for mob violence or extra-judicial punishment, ${ }^{101}$ threats of legal action against the suspect's family members, ${ }^{102}$ and the extent to which sophisticated methods such as the "false friend" were employed during the interrogation. ${ }^{103}$ Second, the Court looked at the idiosyncratic characteristics of the suspect, such as his age, ${ }^{104}$ his race, ${ }^{105}$ his education, intelligence, and socio-economic status, ${ }^{106}$ his prior experience with the criminal justice system, ${ }^{107}$ and his general physical and psychological state, including whether he was under the influence of drugs or alcohol. ${ }^{108}$

As might be imagined, such an elusive test as the "overborne will" standard, by which multiple factors were relevant but none was dispositive, generated considerable criticism. ${ }^{109}$ Not only was the standard indeterminate based solely on the objective factors of the interrogation, but that indeterminacy was exacerbated by the fact that the question of coercion also depended on the idiosyncratic characteristics of the suspect, many of which might not even be known to the police at the time of the interrogation. Even Justice Frankfurter, who generally

96 See, e.g., Darwin v. Connecticut, 391 U.S. 346, 349 (1968) (per curiam); Clewis, 386 U.S. at 712; Davis, 384 U.S. at 744-46; Haynes v. Washington, 373 U.S. 503, 504 (1963); Gallegos, 370 U.S. at 54-55; Culombe, 367 U.S. at 601 (plurality).

97 See, e.g., Clewis, 386 U.S. at 709-10; Ward v. Texas, 316 U.S. 547, 551, 555 (1942).

98 See, e.g., Greenwald, 390 U.S. at 520-21; Clewis, 386 U.S. at 710-11; Davis, 384 U.S. at 739, 740-41; Johnson v. New Jersey, 384 U.S. 719, 730-31 (1966).

99 See, e.g., Clewis, 386 U.S. at 709; Gallegos, 370 U.S. at 55; Reck v. Pate, 367 U.S. 433, 441 (1961); Payne, 356 U.S. at 567.

100 See, e.g., Greenwald, 390 U.S. at 520-21; Johnson, 384 U.S. at 730-31; Haynes, 373 U.S. at 504 .

101 See, e.g., Thomas v. Arizona, 356 U.S. 390, 401 (1958).

102 See Lynumn v. Illinois, 372 U.S. 528, 534 (1963); Harris v. South Carolina, 338 U.S. 68, 70 (1949).

103 See Spano v. New York, 360 U.S. 315, 323 (1959); Thomas, 356 U.S. at 402.

104 See Gallegos, 370 U.S. at 52-55 (1962); Blackburn v. Alabama, 361 U.S. 199, 208 n.7 (1960); Spano, 360 U.S. at 321.

105 See Clewis v. Texas, 386 U.S. 707, 712 (1967); Davis v. North Carolina, 384 U.S. 737, 742 (1966); Ward v. Texas, 316 U.S. 547, 555 (1942); Chambers v. Florida, 309 U.S. 227, 238 (1940); see also Ashcraft v. Tennessee, 322 U.S. 143, 162 (1944) (Jackson, J., dissenting) ("[T] always has considered the confessor's strength or weakness, whether he was educated or illiterate, intelligent or moronic, well or ill, Negro or white.").

106 See Greenwald v. Wisconsin, 390 U.S. 519, 519 (1968); Clewis, 386 U.S. at 712.

107 See Clewis, 386 U.S. at 712; Lynumn, 372 U.S. at 534; Reck v. Pate, 367 U.S. 433, 441 (1961); Spano, 360 U.S. at 321.

108 See Beecher v. Alabama, 389 U.S. 35, 36-38 (1967); Townsend v. Sain, 372 U.S. 293, 308 (1963).

109 See Reck, 367 U.S. at 455 (Clark, J., dissenting) (decrying "the elusive, measureless standard of psychological coercion heretofore developed in this Court by accretion on almost an $a d$ hoc, case-by-case basis"); Ashcraft, 322 U.S. at 163 (Jackson, J., dissenting) ("No one can regard the rule of exclusion dependent on the state of the individual's will as an easy one to apply."). 
supported the case-by-case accretion of doctrine so characteristic of the fundamental fairness methodology, had to acknowledge the drawbacks of the Court's approach when he wrote for a plurality in 1962: "It is impossible for this Court, in enforcing the Fourteenth Amendment, to attempt precisely to delimit, or to surround with specific, all-inclusive restrictions, the power of interrogation allowed to state law enforcement officers in obtaining confessions." ${ }^{\prime 10}$ One can almost hear the weariness in Chief Justice Warren's voice in the opening line of Spano v. New York, decided in 1959: "This is another in the long line of cases presenting the question whether a confession was properly admitted into evidence under the Fourteenth Amendment."

At the same time, the Justices who pressed for total incorporation provided a steady drumbeat of dissent from analyzing coercive interrogation as anything but a Self-Incrimination Clause issue. Justice Douglas, joined by Justice Black, complained in dissent in 1953 that the Court had sanctioned a practice in "plain violation of the command of the Fifth Amendment, made applicable to the States by the Fourteenth, that no man can be compelled to testify against himself."112 Only a year later, this view began to appear in majority opinions, when, in an opinion by Justice Black, the Court wrote: "[C]oerced confessions cannot be admitted as evidence in criminal trials. Some members of the Court reach this conclusion because of their belief that the Fourteenth Amendment makes applicable to the states the Fifth Amendment's ban against compulsory selfincrimination." 113

Finally, in 1964, a year after Gideon made the Assistance of Counsel Clause of the Sixth Amendment applicable to the States via the Fourteenth Amendment, the Court held in Malloy v. Hogan ${ }^{114}$ that the Self-Incrimination Clause applied to the States as well. Although Malloy did not involve police interrogation, the case opened up the possibility of recognizing the Self-Incrimination Clause as the most textually appropriate home for a constraint on state interrogation practices. Indeed, as the Court would later write: "The standard of voluntariness which has evolved in state cases under the Due Process Clause of the Fourteenth Amendment is the same general standard which applied in federal prosecutions - a standard grounded in the policies of the privilege against self-incrimination." ${ }^{\text {115 }}$ But while Malloy provided a textual hook for the Court's regulation of police interrogations under a regime of incorporation, in and of itself the case provided no further doctrinal clarity. After all, the question of whether a statement was "compelled" by interrogation tactics is no easier to answer than the question whether the statement

\footnotetext{
110 Culombe v. Connecticut, 367 U.S. 568, 601 (1961) (plurality opinion).

111360 U.S. 315,315 (1959).

112 Stein v. New York, 346 U.S. 156, 208 (1953) (Douglas, J., joined by Black, J., dissenting) (citations omitted), overruled by Jackson v. Denno, 378 U.S. 368 (1964).

113 Leyra v. Denno, 347 U.S. 556, 558 n.3 (1954).

114378 U.S. 1, 6-8 (1964).

115 Davis v. North Carolina, 384 U.S. 737, 740 (1966).
} 
was coerced.

Two years later, the Court decided Miranda v. Arizona. ${ }^{116}$ The Court first canvassed various interrogation tactics that police use to extract confessions, such as positing the guilt of the suspect as a certainty, minimization of the seriousness of the offense and offering excuses or justifications for it, discouraging consultation with counsel, and engaging in trickery, such as the "good cop/bad cop" routine and rigged line-ups. ${ }^{117}$ Importantly, the Court never claimed that the use of these stratagems, alone or in combination, amounted to a due process violation. Indeed, the Court noted that in the cases before it, the confessions might not have been coerced when measured by the conventional "overborne will" standard. ${ }^{118}$ However, the Court held that, in light of these tactics, when a suspect is interrogated in custody, "the privilege against self-incrimination is jeopardized." "119 Accordingly, the Court held, if the police want to secure admissible statements, they must, prior to obtaining such statements via custodial interrogation, administer the now-famous Miranda warnings and obtain a waiver. ${ }^{120}$

As with Gideon, the decision in Miranda was intimately bound up in the Court's incorporation project. Incorporation of the Self-Incrimination Clause meant that pre-existing Fifth Amendment doctrine now applied to the States. ${ }^{121}$ Generously interpreting its precedents in federal cases, particularly Bram v. United States, ${ }^{122}$ the Court found that it had "clearly establishe[d]" the application of the privilege "to incommunicado interrogation." 123 The court thus found "an intimate connection between the privilege against self-incrimination and police custodial questioning." 124 The Court concluded that, in both state and federal cases, "the privilege is fully applicable during a period of custodial interrogation." ${ }^{\text {. }} 25$

The innovation of Miranda v. Arizona thus was, at least, twofold. First, the decision broke ground in squarely placing police interrogation within the ambit of the Fifth Amendment's Self-Incrimination Clause rather than —or, as we shall see,

116384 U.S. 436 (1966).

117 See id. at 449-54.

118 See id. at 457 ("In these cases, we might not find the defendants' statements to have been involuntary in traditional terms.").

119 Id. at 478.

120 See id. at $478-79$.

121 See id. at 464 (observing that in the cases incorporating the Clause, the Court "applied the existing Fifth Amendment standards to the case before [it]"); see also id. at $464 \mathrm{n} .33$ ("The decisions of this Court have guaranteed the same procedural protection for the defendant whether his confession was used in federal or state court.").

122 See id. at 461 ("'In criminal trials, in the courts of the United States, wherever a question arises whether a confession is incompetent because not voluntary, the issue is controlled by [the SelfIncrimination Clause]." (quoting Bram v. United States, 168 U.S. 532, 542 (1897)).

123 Id. at 463.

$124 I d$. at 458 .

125 Id. at $460-61$. 
in addition to-more general notions of due process. Second, the decision put to one side the multitude of factors the Court had relied upon in the past in deciding whether confessions had been freely given. Instead, the Court pointed to one overriding factor: the very fact of custodial interrogation. The Court determined that in the atmosphere of custodial interrogation, compulsion to incriminate oneself is "inherent." "26 The Court held that the only way to dissipate this inherent compulsion, and thereby secure the admissibility of statements taken in custodial interrogation, is to warn the suspect of his or her rights and obtain a waiver of those rights. ${ }^{127}$ "The Miranda rule thus establishes a conclusive presumption that, without the appropriate warnings and waiver, any response by a suspect to custodial interrogation has been 'compelled' within the meaning of the SelfIncrimination Clause and therefore cannot be used against that suspect at trial."128

Yet the Court's old due process voluntariness test survived Miranda. "[E]ven after holding that the Fifth Amendment privilege against compulsory selfincrimination applies in the context of custodial interrogations, and is binding on the States, the Court has continued to measure confessions against the requirements of due process." 129 Thus, in cases where the dictates of Miranda do not apply because the suspect either is not in custody or is not being interrogated, courts must still measure the voluntariness of a resulting confession based on the old "overborne will" standard. ${ }^{130}$ More importantly, the due process voluntariness test also applies in those situations where the Miranda constraints have been satisfied: where the suspect has been read his rights and waives those rights. ${ }^{131}$ It is to that class of cases this Article will shortly turn.

It will be helpful at this point to observe the many similarities between Gideon and Miranda. As noted already, each jurisprudential line stems from an inter-racial crime from the highly racialized criminal justice system of the Deep South. Each case follows a decades-long failed experiment in using a nebulous, multi-factored standard characteristic of the "fundamental fairness" method of interpreting the Due Process Clause of the Fourteenth Amendment. Both standards looked to both the objective facts - the court proceedings on the one hand, and the interrogation on the other-and the idiosyncratic characteristics of the suspect or defendant. Both standards were also retrospective in that they could be applied only after the fact: Given what occurred at trial, was the appointment of counsel a requirement of due process? Given what occurred during the

126 See id. at $458,467$.

127 See id. at 444, 479.

128 Mannheimer, supra note 27, at 71.

129 Miller v. Fenton, 474 U.S. 104, 110 (1985) (citations omitted); see also Dickerson v. United States, 530 U.S. 428, 433 (2000) ("Over time, our cases recognized two constitutional bases for the requirement that a confession be voluntary to be admitted into evidence: the Fifth Amendment right against self-incrimination and the Due Process Clause of the Fourteenth Amendment.").

130 See Mannheimer, supra note 27, at 71-72.

131 See id. 
interrogation, did the tactics amount to a deprivation of due process? In each case, the experiment failed because the resulting standard led to inconsistent, arbitrary, and unpredictable results. In each case, the multi-factored standard was replaced with a prospective, bright-line rule: state court judges must appoint counsel at the outset of every serious criminal case, and state police must provide warnings before custodial interrogation in order to obtain admissible statements. And, finally, each rule can be stated as a conclusive presumption. Gideon can be read as creating a conclusive presumption that the pendency "of a serious criminal charge" establishes the special circumstances required by Betts, ${ }^{132}$ and Miranda can be read as conclusively presuming that custodial interrogation is compulsive in the absence of warnings to dissipate the compulsion.

\section{THE UNDOING OF GIDEON AND MIRANDA}

Fifty years later, it is difficult to find anyone who thinks that either the Gideon or the Miranda story has a happy ending. Rather, the conventional account is that both have been undone by later developments. While there are several explanations for their undoing, the prime suspect in each case is the establishment of a presumption that runs counter to the conclusive presumption created by the case itself.

\section{A. The Undoing of Gideon: The Presumption of Attorney Competence}

To be sure, Gideon started out in a promising fashion. It was a unanimous decision on a Court that included Justice Harlan, the last anti-incorporationist stalwart. The result in Gideon was advocated by a unique amicus brief supported by the attorneys general of nearly half the States. ${ }^{133}$ In Gideon's aftermath, Judge Friendly reported: "There is nigh unanimous applause for the insistence that persons charged with serious crime shall receive the assistance of counsel at their pleas and trials." ${ }^{134}$ But that Gideon has been a failure is, at least among those in the know, not a proposition that requires defending but a given in need only of an explanation. ${ }^{135}$

\footnotetext{
132 Gideon v. Wainwright, 372 U.S. 335, 351 (1963) (Harlan, J., concurring).

133 See Bruce A. Green, Gideon's Amici: Why Do Prosecutors So Rarely Defend the Rights of the Accused?, 122 YALE L.J. 2336, 2342 (2013).

134 Friendly, supra note 36, at 931.

135 See Vivian O. Berger, The Supreme Court and Defense Counsel: Old Roads, New Paths-A Dead End?, 86 Colum. L. Rev. 9, 61 (1986) (recognizing that "the general opinion [is] that Gideon's promise 'rings hollow' too often”); Donald A. Dripps, Up From Gideon, 45 TEX. TECH. L. REV. 113, 114 (2012) ("[T] he overwhelming weight of informed opinion[] is that Gideon has not succeeded in providing typical indigent defendants with a competent and vigorous defense."); Lawrence C. Marshall, Gideon's Paradox, 73 Fordham L. Rev. 955, 960 (2004) (“[D]espite the widespread acceptance of Gideon, there remains a systemic failure in many areas of the country to actually follow the essence of the ruling in Gideon.").
} 
There are two main culprits typically cited for the undoing of Gideon, one doctrinal and the other non-doctrinal. The non-doctrinal explanation is the lack of political will at the state and local level to fully fund Gideon's "unfunded mandate."136 The result is that public defenders are underfunded ${ }^{137}$ and overworked. ${ }^{138}$ Low pay prevents some highly skilled attorneys from even considering working as public defenders. And staggering caseloads often force the hardy few who go into criminal defense work to triage their cases in such a way that many indigent criminal defendants proceed through the system without adequate care paid to their cases. ${ }^{139}$

These problems are only exacerbated in jurisdictions with no permanent public defender office, where indigent defense is handled by an individual appointment system. Fee caps encourage lawyers to do less work on their cases in order to maximize their hourly wages. ${ }^{140}$ A "go along to get along" ethos sometimes prevails, where defense attorneys do not contest charges too vigorously and plead an inordinate number of cases in exchange (implicitly, of course) for more assignments. ${ }^{141}$ As repeat players in the process, defense attorneys in these systems might align their interests with prosecutors and judges in moving the system along, rather than with their clients in seeking the best possible case outcome. ${ }^{142}$

As compelling as this non-doctrinal explanation is for the failure of Gideon, it hinges almost entirely on the doctrinal explanation: the Supreme Court's decision in Strickland v. Washington. ${ }^{143}$ In Strickland, the Court set a low bar for appointed

136 Stephen B. Bright \& Sia M. Sanneh, Fifty Years of Defiance and Resistance After Gideon v. Wainwright, 122 YALE L.J. 2150, 2174 (2013) ("[M]ost state governments have treated the Supreme Court's decision in Gideon not as a bright star pointing the way to justice, but as an unfunded mandate to be resisted.").

137 See Dripps, supra note 3, at 924 ("Legislators have consistently failed to provide the levels of funding that would be required for even minimally adequate representation."); see also Benjamin H. Barton, Against Civil Gideon (and for Pro Se Court Reform), 62 Fla. L. REv. 1227, 1251-52 (2010) (canvassing instances of persistent underfunding of indigent defense).

${ }_{138}$ See Barton, supra note 137, at 1252 ("The funding problems lead inevitably to crippling caseloads."); Dripps, supra note 3, at 901 (observing that "most defendants are prosecuted in jurisdictions" where caseloads greatly exceed the American Bar Association recommendations for maximum caseloads for defense attorneys).

139 See generally John B. Mitchell, In (Slightly Uncomfortable) Defense of "Triage" by Public Defenders, 39 VAL. U. L. REV. 925 (2005); see also Barton, supra note 137, at 1253 (relating comment from public defender that caseload pressures require that attorneys limit their time to an average of " 3.8 hours per case, including serious felony cases."” (quoting Mary Sue Backus \& Paul Marcus, The Right to Counsel in Criminal Cases, A National Crisis, 57 Hastings L.J. 1031, 1058 (2006))); Berger, supra note 135, at 61 (pointing to "the crushing caseloads of public defenders" as a reason for poor quality defense work); Dripps, supra note 3, at 890 n.30 ("Many, perhaps most, Strickland violations are mediated by caseload pressures.").

140 See Barton, supra note 137 , at 1253.

141 See id.

142 See id. at 1254.

143466 U.S 668 (1984). 
counsel to meet in order to be considered constitutionally effective. It is Strickland that has been widely blamed for the perceived failure to live up to the promise of Gideon. ${ }^{144}$ The Strickland standard has permitted some "grossly incompetent" lawyering to pass constitutional muster in a not insubstantial number of cases. ${ }^{145}$ Had the Court imposed a more stringent constitutional standard for the effective assistance of counsel, state convictions would more consistently be reversed and bounced back to state court for retrial. Recalcitrant state and local governments would have little choice but to pony up the funds required to meet such a higher standard by paying public defenders more and hiring more of them. ${ }^{146}$ But because state legislators know that exceedingly few defendants will be able to show that their legal representation was so faulty as to satisfy the Strickland standard, they are secure in underfunding indigent criminal defense with few consequences. ${ }^{147}$ Anyone who believes that Gideon has largely failed, therefore, must examine Strickland closely.

Prior to Gideon, the Supreme Court had said little about the constitutional requirement of effective assistance of counsel even in cases where the defendant clearly had a right to counsel. Powell made reasonably clear that effective assistance of counsel required sufficient time to prepare for trial, but in that case, as in Avery $v$. Alabama, ${ }^{148}$ the alleged lack of time to prepare was the fault of the court, not counsel. In some early cases, the Court found a due process violation where the appointed attorney did not confer with the defendant until trial or

144 See Dripps, supra note 135, at 120 ("The Strickland standard is widely regarded as practically toothless."); Dripps, supra note 3, at 899 ("Strickland has been the subject of sustained academic criticism since it came down."); George C. Thomas, III, History's Lesson for the Right to Counsel, 2004 U. ILl. L. REV. 543, 546-47 (2004) ("The Court's attempt to set standards in Strickland v. Washington is almost universally viewed as a failure." (footnote omitted)).

145 Marshall, supra note 135, at 968 (concluding that "grossly incompetent lawyers whom none of us would trust with traffic offenses are being entrusted with the lives and liberty of indigent defendants.”); Stephen F. Smith, Taking Strickland Claims Seriously, 93 MARQ. L. REV. 515, 542 (2009) (arguing that Strickland has led "courts [to] reject ineffectiveness challenges to a wide array of stunningly incompetent and unprofessional representation").

146 See Dripps, supra note 3, at 899 ("If the Supreme Court had adopted a robust standard of effective assistance, legislatures would have faced a forced choice between allocating dramatically more resources to indigent defense and scaling back the number of felony prosecutions."); Smith, supra note 145, at 544 ("If, as is commonly supposed, ineffective representation is largely a function of the severe resource constraints the political process imposes on lawyers for indigent defendants, a toothless constitutional standard of effective representation ... virtually invites legislatures to continue underfunding indigent defense.").

147 Barton, supra note 137, at 1259 ("[I]neffective assistance of counsel claims have hardly proven an effective protection against the individual woes of an underfunded, overburdened system of indigent defense."); Dripps, supra note 3, at 903 ("Legislatures disinclined to fund indigent defense know that the failure to provide effective representation will lead to the reversal of few if any convictions."); Smith, supra note 145, at 544 ("[A] more demanding ineffectiveness standard can help counteract the legislative strategy of using resource constraints [and] underfunding will no longer remain a cost-free strategy.").

148308 U.S. 444, 447-49 (1940). 
otherwise abandoned him. ${ }^{149}$ But the Court did not address cases involving less obvious forms of attorney error.

However, the federal circuit courts did. They uniformly adopted a standard for effective assistance based on the fundamental fairness methodology ascendant at the time, despite the fact that the Sixth Amendment directly applied in federal cases. The courts reasoned that the Sixth Amendment guaranteed only counsel; effectiveness of counsel had to be measured by the dictates of the Due Process Clause of the Fifth Amendment in federal cases. ${ }^{150}$ Thus, the standard that was uniformly adopted ${ }^{151}$ was pitched in the language of the nebulous, totality-of-thecircumstances standards of due process: counsel was ineffective only when his or her performance "shocked the conscience of the court and made the proceedings a farce and a mockery of justice." 152 This was a difficult test for defendants to meet, and courts routinely "rejected ineffective assistance of counsel claims unless counsel was grossly incompetent and provided intolerable representation."

Subsequent to Gideon, and in the throes of full-on incorporation of the Sixth Amendment, the Supreme Court began to send signals to the lower courts that the appropriate Sixth Amendment standard for effective assistance of counsel was not as onerous as the "farce and mockery" test. ${ }^{154}$ Eventually, every federal circuit court moved off the "farce and mockery" approach and adopted a standard less imbued with the rhetoric of "fundamental fairness" and "shocking to the conscience." 155 Yet differences in the details of the standards adopted by each court necessitated that the Supreme Court step in to clarify the Sixth Amendment standard. ${ }^{156}$ That clarification came in Strickland $v$. Washington. ${ }^{157}$

In Strickland, the defendant, who pled guilty and was sentenced to death in Florida for three capital crimes, sought relief from his death sentences by claiming

149 See White v. Ragen, 324 U.S. 760, 762-63 (1945) (attorney "refused to do anything for [the defendant] unless [he] had some money," and refused to call a witness on the defendant's behalf because counsel had another case to attend to.); Hawk v. Olson, 326 U.S. 271, $276-77$ (1945) (allegation that during the only pre-trial conferral between counsel and defendant, counsel tried to force defendant to plead guilty, then abandoned him when he refused).

150 Sanjay K. Chhablani, Disentangling the Right to Effective Assistance of Counsel, 60 SYRACUSE L. REV. 1, 13 (2009).

151 See id. at 13-16.

152 Diggs v. Welch, 148 F.2d 667, 670 (D.C. Cir. 1945). See also Berger, supra note 135, at 68 ("After-the-fact constitutional appraisal of attorney conduct rested solely on the vague, residual due process right to a fair trial.").

153 Chhablani, supra note 150 , at 14.

154 See id. at 19 (observing that "[t]he Court [in 1970] signaled that the 'farce and mockery' standard was too restrictive and that the right to effective assistance of counsel embodied in the Sixth Amendment called for a different approach for measuring the adequacy of counsel's conduct.").

${ }^{155}$ See id. at 21 ("[P]rior to the Court's decision in Strickland v. Washington, every Circuit Court had adopted a Sixth Amendment-based approach to evaluating counsel's effectiveness.”).

156 See id. at 21-34.

157466 U.S 668 (1984). 
that he had not been provided the effective assistance of counsel. ${ }^{158}$ He asserted that various deficiencies of his appointed attorney led to his death sentence, including counsel's failure to fully investigate possible character witnesses, to seek a pre-sentence report, to present effective arguments to the sentencing judge, to cross-examine the prosecution's medical experts, and to request a psychiatric report for his client after he claimed he committed his crimes in a state of extreme stress. ${ }^{159}$

Rejecting this claim, the Supreme Court set out the now-famous two-pronged analysis of claims of ineffective assistance of counsel:

A convicted defendant's claim that counsel's assistance was so defective as to require reversal of a conviction or death sentence has two components. First, the defendant must show that counsel's performance was deficient. This requires showing that counsel made errors so serious that counsel was not functioning as the "counsel" guaranteed the defendant by the Sixth Amendment. Second, the defendant must show that the deficient performance prejudiced the defense. This requires showing that counsel's errors were so serious as to deprive the defendant of a fair trial, a trial whose result is reliable. ${ }^{160}$

These prongs have come to be known as the "performance prong" and the "prejudice prong." The defendant must win on both prongs to gain relief. ${ }^{161}$

The Court wrote that the touchstone for examining attorney performance, prong one, "is that of reasonably effective assistance," "162 which is to say "reasonableness under prevailing professional norms." 163 The question is whether "counsel's representation fell below an objective standard of reasonableness." 164 Beyond that, the Court declined to articulate any detailed "checklist" to evaluate the effectiveness of counsel in any given case, in part because such an attempt would be fruitless in light of the endless "variety of circumstances faced by counsel" in the various types of cases counsel must address, and the variety of responses to that array of situations. ${ }^{165}$

The Court also created a strong presumption for courts to engage in when assessing the performance prong, a presumption of attorney competence, which is to say that virtually any attorney will satisfy Gideon. The Strickland Court wrote that "a court must indulge a strong presumption that counsel's conduct falls within

See id. at 675.

159 See id.

$160 I d$. at 687.

161 See id.

162 Id.

$163 I d$. at 688 .

$164 I d$.

165 Id. at $688-89$. 
the wide range of reasonable professional assistance."166 Later, the Court reiterated that "counsel is strongly presumed to have rendered adequate assistance." "If7 the Gideon presumption is that the existence of criminal charges against a defendant is itself a "special circumstance" requiring the assistance of counsel, then the presumption of attorney competence is a powerful counterpresumption. And this was no rhetorical flourish; it was a critical part of the opinion. ${ }^{168}$

To the extent that Strickland is responsible for what is widely perceived as a failure to live up to the promise of Gideon, some have suggested that the performance prong of Strickland with its presumption of attorney competence has done a great deal of the harm. ${ }^{169}$ An empirical study of Strickland claims in the federal circuit courts as of May 1988 found that nearly a third of such claims were rejected solely because Strickland's performance prong had not been satisfied. ${ }^{170}$

166 Id. at 689.

167 Id. at 690. The Court also repeatedly articulated this presumption in terms of the "deference" to be given counsel. See id. at 689 ("Judicial scrutiny of counsel's performance must be highly deferential."); id. at 691 (instructing courts to "apply[] a heavy measure of deference to counsel's judgments").

168 Berger, supra note 135 , at 82 ("[T] he majority alluded constantly to the stated presumption of counsel competence."). To be sure, circuit courts prior to Strickland had spoken of a presumption of attorney competence. See, e.g., United States ex rel. Feeley v. Ragen, 166 F.2d 976, 980 (7th Cir. 1948) ("Whenever the court in good faith appoints or accepts the appearance of a member of the bar in good standing to represent a defendant, the presumption is that such counsel is competent. Otherwise, he would not be in good standing at the bar and accepted by the court."). However, the presumption was never stated in such a way as to make it virtually irrebuttable. Rather, it appears that this presumption of attorney competence was established merely to make clear that the defendant bore the burden of proving an ineffectiveness claim. See Maye v. Pescor, 162 F.2d 641, 643 (8th Cir. 1947) ("Counsel appointed by a court to represent an accused is presumed to be competent, and the burden rests upon the petitioner to prove such incompetency.”); Diggs v. Welch, 148 F.2d 667, 668 (D.C. Cir. 1945) ("We must assume that the court appointed a reputable member of the bar in whom it had confidence.").

169 See Smith, supra note 145, at 522 ("Here is where the Court seriously undermined the ideal of effective representation.”).

170 See Martin C. Calhoun, Note, How to Thread the Needle: Toward a Checklist-Based Standard for Evaluating Ineffective Assistance of Counsel Claims, 77 GEO. L.J. 413, 458 app. I (1988) (finding that $32.34 \%$ of claims fell into this category). This is not to downplay the purported defects of the prejudice prong. The mischief of the prejudice prong is that it places the burden of proof, and thus the burden of uncertainty, on the defendant rather than on the prosecution. This is contrary to conventional harmless error analysis, which places the burden on the prosecution once constitutional error has been shown. See Chapman v. California, 386 U.S. 18, 24 (1967) (holding that "the beneficiary of a constitutional error [must] prove beyond a reasonable doubt that the error complained of did not contribute to the verdict obtained."). This shifting of the burden is problematic, for even in cases where defendants can satisfy the court that counsel performed below a standard of reasonable competence, uncertainty, ambiguity, or silence in the record will mean that prejudice has not been established and the defendant will lose. Presumably, in many cases, a defendant who loses on the prejudice prong would also lose pursuant to a more conventional harmless error analysis. But concededly, in some unknown number of cases, the burden-shifting of Strickland's prejudice prong affects the outcome. On the other hand, a presumption is necessary 
To understand the mischief wrought by the presumption of attorney competence embedded in the performance prong, imagine a defendant who can actually demonstrate that the outcome would have been different but for the attorney's errors. Such a defendant will still lose unless he or she can overcome the presumption of attorney competence. As Professor George Thomas put it:

Because a defendant must meet both prongs of Strickland, some defendants whose lawyer cost them a probable acquittal will not be permitted a new trial because a reviewing court will find the overall representation not bad enough to rebut the resumption of reasonableness.... Strickland thus sanctions, under the Sixth Amendment, a system in which lawyers literally cost their clients an acquittal. ${ }^{171}$

The presumption of attorney competence operates as a sort of "rational basis" test, signaling to lower courts that they should reject ineffectiveness claims so long as there is "any conceivable basis for rationalizing the attorney's actions." "This is true even if that post hoc rationalization obviously never occurred to the attorney. The presumption of attorney competence thus insulates "all but the most deeply flawed convictions" from reversal. ${ }^{173}$

Professor Stephen Smith has shown how the application of the Court's newlyminted standard in Strickland itself operated in this fashion. Although the trial attorney had argued to the sentencing judge that the defendant should not receive the death penalty because he was under significant emotional distress at the time of the crime, the attorney's failure to back up that argument with evidence that might have been obtained via expert psychiatric testimony was not deficient, the Court reasoned, because it was an acceptable strategy to focus on the defendant's acceptance of responsibility. ${ }^{174}$ Yet, that was not the attorney's strategy at all, for he "actually argued emotional distress." 175 The Strickland counter-presumption

because the burden of proof must lie with someone. Thus, the Strickland Court's prejudice prong is questionable, not because it creates a presumption, but because of the nature of that presumption.

171 Thomas, supra note 144 , at 553.

172 Smith, supra note 145, at 520-21; see Stephanos Bibas, The Psychology of Hindsight and After-the-Fact Review of Ineffective Assistance of Counsel, 2004 UTAH L. REV. 1, 6 ("Strickland winds up being almost as toothless as rational-basis review under the Equal Protection Clause, which also rests on post hoc rationalizations instead of actual reasons."); Stephen B. Bright, Counsel for the Poor: The Death Sentence Not for the Worst Crime but for the Worst Lawyer, 103 YALE L.J. 1835, 1858 (1994) ("Errors in judgment and other mistakes may readily be characterized as 'strategy' and 'tactics' and thus are beyond review.").

173 Thomas, supra note 144, at 547; see also Gary Goodpaster, The Adversary System, Advocacy, and Effective Assistance of Counsel in Criminal Cases, 14 N.Y.U. REv. L. \& Soc. CHANGE 59, 78 (1986) (observing that the presumption of attorney competence "virtually mandates that reviewing courts find that most defense attorneys, no matter what they have done or failed to do, are competent").

174 See Smith, supra note 145 , at 521-22.

$175 I d$. at 522. 
thus allows courts to treat the word "strategy" as a talismanic device to justify virtually any deficiency in counsel's performance. ${ }^{176}$ "[T] he presumption of [attorney] competence serves to mask what in many cases are not 'tactical choices' but simple blunders." 177

The presumption of attorney competence thus constrains judicial discretion. It largely precludes judges from determining whether the attorney actually had some strategy in mind at the time of his or her action or inaction and, if so, whether that strategy was consistent with prevailing professional norms. Yet we generally conceive of the judge's role, not as "requiring reflexive deference to claimed exercises of strategic judgment," but as "demand[ing] that judges carefully probe claims of 'strategy' for accuracy (as an account of counsel's actual thought process at the time of the challenged decision) and reasonableness in light of the circumstances of the case." 178 The presumption of attorney competence requires judges to pass on ineffectiveness claims without performing this careful, probing work. This constraint of judicial discretion simplifies the judicial role, but at the cost of denying real scrutiny to questionable decisions or non-decisions by trial attorneys, a cost that is ultimately borne by their indigent clients

At the same time, the presumption of attorney competence sends exactly the opposite signal to defense counsel, the other set of institutional actors to which it is addressed. Far from constraining their conduct, Strickland, for them, is liberating. The presumption of attorney competence ensures counsel that their decisions will not be second-guessed except in the most extreme and rare cases. In effect, this presumption provides "safe harbor," and a quite roomy one at that. So long as their conduct can be rationalized later as the product of strategy, it will not be questioned.

Recent empirical work leads to the sobering conclusion that we may have, in essence, come full circle from Betts. The touchstone of the cases decided under the Betts regime was whether a defendant could be thought to adequately defend himself from the forces of the state without a lawyer. The results under that regime were mixed, and the Court sometimes - not often, but sometimesconcluded that a defendant was at least as well off going it alone. ${ }^{179}$ Gideon foreclosed that conclusion by declaring categorically that a counseled defendant

176 Id. (asserting that Strickland permits lower courts "to insulate [attorney] judgments against judicial scrutiny by uttering the magic words of 'strategy' and 'tactics"').

177 Dripps, supra note 3, at 902.

178 Smith, supra note 145, at 538.

${ }^{179}$ See, e.g., Quicksall v. Michigan, 339 U.S. 660, 665-66 (1950) (finding no constitutional violation where defendant pled guilty without asking for counsel and where there was no evidence he was ignorant of his statutory right to counsel); Gryger v. Burke, 334 U.S. 728, 731 (1948) (finding no constitutional violation where sentencing court might have misconstrued statute as providing for mandatory life sentence rather than leaving discretion with judge); Bute v. Illinois, 333 U.S. 640, 670-74 (1948) (finding no constitutional violation where charges of child molestation were relatively simple, no indication of a good defense appeared on the record, and defendant never requested counsel). 
would always receive a fairer trial than an uncounseled one. But Professor Erica Hashimoto's work on pro se defendants suggests that this categorical claim was incorrect: her empirical study strongly suggests that pro se defendants charged with felonies in state court fare no worse than defendants represented by counsel, and indicates that some pro se defendants actually do better. ${ }^{180}$ It may be that counseled defendants did better in more complex cases. ${ }^{181}$ But, importantly, it is this class of cases where a right to counsel ought to have been found when Betts was properly applied. This suggests not that Gideon was incorrect ${ }^{182}$ but that the quality of counsel under the Strickland regime is so spotty that many defendants would be at least as well off-and some would be better off - if Gideon had never been decided. ${ }^{183}$

\section{B. The Undoing of Miranda: The Presumption of Non-Coercion}

Miranda was, from the outset, a less promising decision than Gideon. ${ }^{184}$ The Court divided 5-4, and the dissenters predicted that the decision signaled the end to the highly useful crime-fighting tool of custodial interrogation. ${ }^{185}$ Even politicians soon got in on the act. Miranda, they said, handcuffed the police and represented illegitimate legislating from the bench. ${ }^{186}$ It is no over-statement to say that

180 See Erica J. Hashimoto, Defending the Right of Self-Representation: An Empirical Look at the Pro Se Felony Defendant, 85 N.C. L. REv. 423, 447-50 (2007); see also Dripps, supra note 135, at 124 (citing Hashimoto's work for same proposition).

181 See Benjamin H. Barton \& Stephanos Bibas, Triaging Appointed-Counsel Funding and Pro Se Access to Justice, 160 U. PA. L. REV. 967, 992 (2012) ("Hashimoto's research indicates that lawyers appear to add less value in simple misdemeanor cases than in more complex and serious cases." (citing Erica J. Hashimoto, The Price of Misdemeanor Representation, 49 WM. \& MARY L. REV. 461, 496 (2007))).

${ }^{182}$ See Hashimoto, supra note 180, at 477 ("If pro se defendants do just as well without counsel, does it follow that Gideon overrated the importance of counsel? I think not.").

${ }^{183}$ See Dripps, supra note 135, at 124 (interpreting Hashimoto's findings to suggest that appointed counsel are ineffective in a sufficiently large number of cases to make it advantageous for many defendants to handle their cases pro se). Of course, pursuant to Faretta v. California, 422 U.S. 806, 834 (1975), every competent defendant has the Sixth and Fourteenth Amendment right to defend himself. However, Gideon's promise of counsel may provide a false sense of security to some defendants who would be better off going it alone but who do not realize it.

184 See Dripps, supra note 135, at 115 ("[I]n marked contrast to Miranda, Gideon has never been controversial."); Marshall, supra note 135, at 960 (observing that "of all the major criminal justice decisions of the Warren Court, Gideon is the one that no one seeks to overrule," while "Miranda remains unpopular in many circles").

${ }_{185}$ See Miranda v. Arizona, 384 U.S. 436, 536 (1966) (White, J., joined by Harlan and Stewart, JJ., dissenting) ("[T]he Court . . . for all practical purposes forbids interrogation except in the presence of counsel."); id. at $516 \mathrm{n} .12$ (observing that "“[a]ny lawyer worth his salt will tell the suspect in no uncertain terms to make no statement to police under any circumstances." (quoting Watts v. Indiana, 338 U.S. 49, 59 (1949) (alteration added)).

186 See, e.g., Liva BAKER, MirANDA: CRIME, LAW AND Politics 248 (1983) (recounting Richard Nixon's use of Miranda in 1968 presidential campaign). 
Miranda is one of the most controversial Supreme Court decisions of all time. ${ }^{187}$ But the Miranda rule today is typically criticized at least as much by liberals who claim it does too little as by conservatives who claim it does too much. ${ }^{188}$ How did we get here?

Miranda differed from Gideon in at least one respect relevant here: it is not difficult to nail down when the Gideon conclusive presumption applies. To be sure, there were some initial questions over how serious a criminal offense had to be for the Gideon right to kick in. But once the Court ruled in Argersinger $v$. Hamlin that counsel had to be provided before a defendant could be deprived of liberty, ${ }^{189}$ that issue was put to rest. By contrast, the bright-line rule of Miranda spawned a series of issues that could be addressed using only nebulous standards. The conclusive presumption of coercion applies only where there is (1) custody, (2) interrogation, and (3) absence of waiver. The Court fell back on fuzzy, totalityof-the-circumstances-informed standards to address each of these issues. There is custody where "a suspect's freedom of action is curtailed to a 'degree associated with formal arrest." 190 There is interrogation where there is "either express questioning or ... any words or actions on the part of the police ... that the police should know are reasonably likely to elicit an incriminating response from the suspect."191 And waiver need not be explicit but can be "implied from all the circumstances." 192

One can thus criticize the Court's Miranda jurisprudence for falling back on fuzzy standards in determining when the Miranda conclusive presumption applies. But to quibble about the amorphous nature of the edges of the Miranda rule risks ignoring the more fundamental criticism of Miranda: even where it indisputably applies, it is arguably ineffective in furthering its stated goal of "giv[ing] concrete constitutional guidelines for law enforcement agencies and courts to follow.", 193 To understand why, one must first realize that reliable studies have shown that something on the order of four out of every five suspects waive their Miranda

187 See Richard A. Leo, Questioning the Relevance of Miranda in the Twenty-First Century, 99 Mich. L. REV. 1000, 1026 (2001) (characterizing Miranda as "one of the most well-known and controversial Supreme Court decisions in American history").

188 Compare Joseph D. Grano, Miranda's Constitutional Difficulties: A Reply to Professor Schulhofer, 55 U. CHI. L. REV. 174 (1988) (arguing that Miranda is an illegitimate exercise of judicial power) with Charles D. Weisselberg, Mourning Miranda, 96 CALIF. L. REV. 1519, 1524 (2008) ("[L]ittle is left of Miranda's vaunted safeguards and what is left is not worth retaining.").

189407 U.S. 25, 37 (1972) ("[N]o person may be imprisoned for any offense, whether classified as petty, misdemeanor, or felony, unless he was represented by counsel at his trial.").

190 Berkemer v. McCarty, 468 U.S. 420, 440 (1984) (quoting California v. Beheler, 463 U.S. 1121, 1125 (1983) (per curiam)).

191 Rhode Island v. Innis, 446 U.S. 291, 300-01 (1980) (footnote omitted).

192 Berghuis v. Thompkins, 130 S. Ct. 2250, 2261 (2010).

193 Miranda v. Arizona, 384 U.S. 436, 442 (1966). Of course, Miranda may have been more successful in advancing other goals such as, most obviously, giving suspects notice of their rights pursuant to the Self-Incrimination Clause, as incorporated. I focus here on the Court's mission, stated in its explanation for the grant of certiorari, of providing clear standards for police and courts. 
rights at the outset of custodial interrogation ${ }^{194}$ and do not later invoke those rights during the interrogation. ${ }^{195}$ Thus, vis-à-vis these eighty percent, Miranda neither advances nor impedes the goal of providing "concrete constitutional guidelines" for the conduct of interrogations. It simply returns a suspect to the status quo ante Miranda. That is to say, these eighty percent of suspects who waive their rights are still supposedly protected by the Court's due process jurisprudence. ${ }^{196}$

But there's the rub. Once a suspect waives his or her Miranda rights, the Miranda "counter-presumption" 197 kicks in and any ensuing statements will almost invariably be deemed to have been freely given. This counter-presumption seems to have first appeared in the Supreme Court doctrine as a throwaway line in Berkemer v. McCarty. The Court there observed that one of the goals of Miranda was to "as much as possible free courts from the task of scrutinizing individual cases to try to determine, after the fact, whether particular confessions were voluntary." 198 The Court then dropped a footnote explaining the effect of the rendition of Miranda warnings on a later claim of coerciveness: "We do not suggest that compliance with Miranda conclusively establishes the voluntariness of a subsequent confession. But cases in which a defendant can make a colorable argument that a self-incriminating statement was 'compelled' despite the fact that the law enforcement authorities adhered to the dictates of Miranda are rare." 199

This curious dictum has been treated as a normative gloss on the doctrine. That is to say, the Berkemer dictum has come to be seen not as an innocuous empirical claim but as an instruction to lower courts that compliance with Miranda ordinarily should insulate later statements from allegations of coercion. ${ }^{200}$ The

194 See Paul G. Cassell \& Bret S. Hayman, Police Interrogation in the 1990s: An Empirical Study of the Effects of Miranda, 43 UCLA L. REV. 839, 860 (1996); Richard A. Leo, Inside the Interrogation Room, 86 J. CRIM. L. \& CRIMINOLOGY 266, 282-83 (1996).

195 See William J. Stuntz, Miranda's Mistake, 99 Mich. L. REV. 975, 988 (2001) (citing studies that show that "invocation during questioning is rare").

196 See Louis Michael Seidman, Brown and Miranda, 80 CALIF. L. REv. 673, 745 (1992) ("In theory . . Miranda did no more than add an additional layer of protection for defendants without depriving them of the right to raise voluntariness claims even if the police had complied with the Miranda requirements."); Welsh S. White, Miranda's Failure To Restrain Pernicious Interrogation Practices, 99 Mich. L. Rev. 1211, 1218 (2001) ("[O]nce the suspect validly waives his Miranda rights, the due process voluntariness test provides the only restriction on police interrogation practices.").

197 See George C. Thomas III, A Philosophical Account of Coerced Self-Incrimination, 5 YALE J. L. \& Human. 79, 102 (1993).

198468 U.S. 420, 433 (1984).

199 Id. at 433 n. 20.

200 See Mark A. Godsey, Reformulating the Miranda Warnings in Light of Contemporary Law and Understandings, 90 MinN. L. REv. 781, 810 (2006) ("If Miranda warnings were provided and waived prior to the confession, the confession is seen as presumptively voluntary."); Patrick A. Malone, "You Have the Right to Remain Silent": Miranda After Twenty Years, 55 AM. SchOlar 367, 378 (1986) ("[W]hen it has been concluded that a suspect waived his rights voluntarily, courts have often leaned on this finding to conclude that the entire subsequent interrogation was properly conducted, even though that is supposed to remain a separate inquiry."); Seidman, supra note 196, at 
dictum was ratified by the Court in Dickerson v. United States, ${ }^{201}$ and a plurality of the Court more recently put its imprimatur on this reading, explaining that "giving the warnings and getting a waiver has generally produced a virtual ticket of admissibility; maintaining that a statement is involuntary even though given after warnings and voluntary waiver of rights requires unusual stamina."202 This presumption of non-coercion instructs lower courts, in the overwhelming run of cases, to admit statements resulting from interrogations without having to address the underlying question of voluntariness, ${ }^{203}$ which remains as convoluted as it was pre-Miranda. ${ }^{204}$ Instead, the focus is on whether the simple and formulaic Miranda requirements have been met. ${ }^{205}$ It may even be that "lower courts conflate the test for determining a valid Miranda waiver with the test for determining a voluntary confession because the tests are so similar." ${ }^{, 206}$ In 2001, Professor Welsh White found that, over the course of the previous two years, there were only five reported cases in which a defendant made a successful federal due process challenge to a confession following a Miranda waiver. ${ }^{207}$

This instruction to the courts, in turn, becomes a guarantee of sorts to the police. The presumption of non-coercion, in effect, provides police with "“a safe

744-45 ("The warning-and-waiver ritual that is at Miranda's core serve[s] to insulate the resulting confessions from claims that they were coerced or involuntary."); Thomas, supra note 197, at 102 (" $\mathrm{Th}[\mathrm{e}]$ emphasis on what the warnings can achieve creates, in effect, a counter-presumption that gives [the police] a regular, routine way to demonstrate that . . . any resulting confession is admissible."); White, supra note 196, at 1217 ("Miranda provides virtually no restrictions . . . on interrogation practices employed after waivers are obtained.").

201530 U.S. 428, 454 (2000).

202 Missouri v. Seibert, 542 U.S. 600, 608-09 (2004) (plurality); accord Weisselberg, supra note 188 , at 1595 .

${ }^{203}$ See Leo, supra note 187, at 1026 (asserting that Miranda "lull[s] judges into admitting confessions with little inquiry into voluntariness"); Seidman, supra note 196, at 745-46 ("[M] any lower courts have adopted an attitude toward voluntariness claims that can only be called cavalier."); White, supra note 196, at 1220 ("A finding that the police have properly informed the suspect of his Miranda rights ... often has the effect of minimizing or eliminating the scrutiny applied to postwaiver interrogation practices.").

204 White, supra note 196, at 1218 ("[T] identical to the pre-Miranda test.").

205 See Leo, supra note 187, at 1025 ("Virtually all observers seem to agree that Miranda has shifted the legal inquiry from whether the confession was voluntarily given to whether the Miranda rights were voluntarily waived."); Malone, supra note 200, at 377 ("Staccato Miranda conversations, with their uniform statements and check-the-box answers, are easier for courts to evaluate than sprawling hours-long interrogation.").

206 White, supra note 196 , at 1220 . This would likely be an acceptable approach where a waiver occurs not at the outset of the interrogation but during the interrogation itself, as in Berghuis v. Thompkins, $130 \mathrm{~S}$. Ct. 2250 (2010). In that case, the Court held that the suspect's confession - the word "yes" in answer to a question - could also serve double duty as his waiver of Miranda rights. See id. at 2257, 2262. In such a case, the question of whether the waiver was voluntary would presumably be exactly the same question as whether the confession was voluntary. However, such cases are probably rare.

207 See White, supra note 196, at 1219-20 \& n.54. In four additional cases, defendants were able to successfully challenge confessions on state due process grounds. See id. 
harbor: if they follow[] the rules, they ha[ve] a fair assurance that a confession [will] be admissible." "208 Worse still, the presumption of non-coercion might actually embolden police to act in ways that might, in an earlier generation, have been deemed coercive. This is because "once the police give the Miranda warnings and obtain a waiver, they can engage in conduct that actually violates the Constitution, and neither the defendant nor the court is likely to stop them."209

Anecdotal evidence supports this concern. Professor Louis Seidman cited "an especially egregious example" of a lower court finding a confession voluntary after Miranda had been satisfied where a suspect was intellectually and mentally disabled, and was threatened by the police with electrocution. ${ }^{210}$ Patrick Malone cited a Mississippi case where the court, in denying suppression, relied on the fact that the suspect had been given Miranda warnings, but the suspect was "a twentyseven-year-old man with a second-grade education, a tested IQ of from 54 to 60, and organic brain disease" and "confessed on the third day of interrogation." 211 As one student commentator put it, it "may well be that the police are freer to use coercive tactics now than they were before" Miranda. ${ }^{212}$ Miranda's counterpresumption thus "furnishe[s] law enforcement with a potent weapon to sanitize otherwise questionable confessions." 213 The simplification of the law that Miranda sought, among its other goals, has come to fruition but it has been achieved on the

208 Weisselberg, supra note 188, at 1595 (quoting CHARLES FRIED, ORDER AND LAW: ARGUING THE REAGAN REVOLUTION-A FIRSTHAND ACCOUNT 45 (1991) (alteration added)); see also Thomas, supra note 197, at 102 ("The most significant effect of Miranda, ironically, may be to make police interrogation a more certain enterprise; even if some confessions are lost because suspects occasionally act on the warnings and remain silent, the confessions that are taken by complying with Mirand $a$ are virtually guaranteed to be admitted into evidence.").

209 John F. Stinneford, The Illusory Eighth Amendment, 63 Am. U. L. REv. 437, 472-73 (2013); see also Gerald Caplan, Questioning Miranda, 38 VAND. L. REV. 1417, 1434 n.90 (1985) ("Because the prosecution usually can prove the voluntariness of the waiver more easily than it can prove the voluntariness of the confession, the exchange of fourteenth amendment for fifth amendment protection has resulted in a net diminution of rights."); Leo, supra note 187, at 1025 (noting that some "suggest[] that as long as Miranda warnings were given, courts ignored interrogation misconduct, freeing the police to coerce suspects as long as they had first Mirandized them").

210 Seidman, supra note 196, at 746 n.241.

211 Malone, supra note 200, at 378.

212 James T. Thomas, Note, Police Use of Trickery as an Interrogation Technique, 32 VAND. L. REV. 1167, 1181 (1979).

213 Alfredo Garcia, Is Miranda Dead, Was it Overruled, or is it Irrelevant? 10 ST. Thomas L. REV. 461, 478 (1998); see also Malone, supra note 200, at 378 ("Miranda in many instances has been used to draw a shroud over the criminal interrogations that the decision was intended to bring into the open."). 
backs of criminal defendants. ${ }^{214}$ Little wonder, then, that police and prosecutors have learned to live with Miranda. ${ }^{215}$

Moreover, the presumption of non-coercion perversely provides the least protection from coercion for suspects who are the most in need of it. Presumably, the twenty percent or so of suspects who invoke their Miranda rights are the savviest, the best educated, the most experienced in the criminal justice system, or, at the least, the most capable of standing firm in the presence of authority figures. Since all of these factors enter into the calculus of coercion, interrogations of the meeker eighty percent or so, all other things being equal, are more likely to be coercive than interrogations of the hardier twenty percent would be. ${ }^{216}$

On one level, the presumption of non-coercion makes sense. Given that the suspect is armed with the knowledge that he or she can stop the interrogation at any time, perhaps we should heavily presume that the interrogation was not coercive if the suspect voluntarily chose to continue. ${ }^{217}$ After all, as the Supreme Court wrote in a related context, "it seems self-evident that one who is told he is free to refuse to answer questions is in a curious posture to later complain that his answers were compelled." ${ }^{218}$ On the other hand, what we might identify as coercion from a perspective exogenous to the interrogation might not seem coercive when viewed from inside the suspect's head. Courts appear most likely to view an interrogation as coercive, for example, when police lie to a suspect in a way that is likely to lead him or her to sacrifice his privilege for seemingly greater concerns. ${ }^{219}$ In such a situation, knowledge of the privilege is obviously useless. And, more generally, the whole point of police use of deception is that the suspect does not know he or she is being deceived.

In any event, my goal is neither to attack nor defend either the presumption of attorney competence or the presumption of non-coercion, but only to identify them and situate them within the larger context of the incorporation debate. It is to the latter project that this Article now turns.

214 See Leo, supra note 187, at 1025 ("The cost of this simplification . . . appears to be borne by the accused.").

215 See Thomas, supra note 197, at 102 ("[W]hile police and prosecutors were initially outraged by Miranda, they rather quickly dropped their opposition and now seem quite content with the Miranda doctrine."); see also Malone, supra note 200, at 377 ("[T] he shift in focus has proven to be a boon to police.").

216 Cf. Garcia, supra note 213, at 474 ("The irony of Miranda lies in the majority's recognition that a suspect who does not ask for counsel is the person most in need of a lawyer's assistance.").

217 See Malone, supra note 200, at 377 ("When a suspect says yes, he understands his Miranda rights, and yes, he waives them, he is generally taken at his word ....").

218 United States v. Washington, 431 U.S. 181, 188 (1977).

219 See, e.g., People v. Thomas, 8 N.E.3d 308, 314-15 (N.Y. 2014) (finding coercion in large part because police repeatedly told suspect that "his disclosure of the circumstances under which he injured his child was essential to assist the doctors attempting to save the child's life" when police knew the child was already brain dead). 


\section{THE MIRANDA AND STRICKLAND COUNTER-PRESUMPTIONS AS THE PRODUCTS OF THE WARREN COURT'S INCORPORATION PROJECT}

The conventional account of the trajectory of Gideon and Miranda relies on a simple political explanation: conservative backlash against what was perceived by some as the liberal excesses of the Warren Court. As Professor Donald Dripps has written: "The basic liberal narrative about constitutional criminal procedure celebrates the Warren Court's project of reforming the criminal process to advance liberty and equality, and condemns the Supreme Court's pro-prosecution turn in the years since Warren's retirement in 1969."220 Not only did the Court become more hostile to claims by defendants in criminal cases generally, but this hostility manifested itself in the Strickland and Miranda counter-presumptions in particular.

However, this political explanation is incomplete. To be sure, it would be naïve to think that politics had nothing to do with the Burger and Rehnquist Courts' cutting back on some of the landmark decisions of the 1960s, particularly Miranda. But this conventional explanation for the Strickland and Miranda counter-presumptions overlooks the fact that both were endorsed by liberal and conservative Justices alike. Remember that the Court first put its imprimatur on the Miranda counter-presumption in Berkemer v. McCarty, a unanimous decision penned by Justice Thurgood Marshall, ${ }^{221}$ probably the most vocal defender of Miranda on the Court. ${ }^{222}$ The Berkemer dictum was later endorsed wholeheartedly by a majority in 2000 that included all members of the Court except Justices Scalia and Thomas. ${ }^{223}$ And it gained even more traction when the four most liberal members of the Court in 2004 declared with apparent approval that "giving the warnings and getting a waiver has generally produced a virtual ticket of admissibility.",224

Strickland, too, cut across ideological lines. It was an 8-1 decision, with only Justice Marshall in dissent. ${ }^{225}$ Even liberal Justice William Brennan joined the majority opinion, dissenting only from the judgment because it ratified a state death sentence. $^{226}$ Indeed, he wrote separately to emphasize his belief that

\footnotetext{
220 Dripps, supra note 3, at 902.

221468 U.S. 420,433 n.20 (1984).

222 For example, Justice Marshall was the lone dissenter, joined not even by his usual liberal companion Justice Brennan, in both Pennsylvania v. Muniz, 496 U.S. 582 (1990) (holding that answers to routine booking questions are admissible even if not preceded by Miranda warnings and waiver), and Illinois v. Perkins, 496 U.S. 292 (1990) (holding that answers to questions by undercover agent in custodial setting are admissible even if not preceded by Miranda warnings and waiver).

223 Dickerson v. United States, 530 U.S. 428, 454 (2000).

224 Missouri v. Seibert, 542 U.S. 600, 608-09 (2004) (plurality).

225 Strickland v. Washington, 466 U.S 668, 668 (1984).

226 See id. at 701 (Brennan, J., concurring in part and dissenting in part) ("I join the Court's opinion but dissent from its judgment. Adhering to my view that the death penalty is in all
} 
Strickland would "provide helpful guidance to courts considering claims of actual ineffectiveness of counsel.",227

The Miranda and Strickland counter-presumptions cannot be understood solely in crass political terms. Rather, they were at least in part the product of the Warren Court's incorporation project. Again, by the time Earl Warren stepped down as Chief Justice, incorporation was fairly complete. The fundamental fairness methodology was on life support, and when Justice John Harlan, its last great defender, left the Court in 1971, the plug was pulled.

Incorporation ushered in an era of rules over standards. But rules, the hallmark of incorporation, can rarely if ever displace standards. When standards pop up again in a different place or form, further rules are required in an attempt to displace them. The Miranda and Strickland counter-presumptions are best understood as "scaffolding" rules created to buttress the primary rules established in Miranda and Gideon. Moreover, these two counter-presumptions were the only reasonably possible options under an incorporationist regime.

\section{A. Step One: From Standards to Rules}

Legal directives differ in the extent to which they provide clear guidelines to the actors to whom they are primarily directed and to the decision-makers who later evaluate the conduct of these actors. As one travels on the spectrum from less to greater clarity and definiteness, one goes from standards to rules. ${ }^{228}$ Keeping in mind that there is no sharp dichotomy between rules and standards but only points on a continuum, ${ }^{229}$ we can use Professor Kathleen Sullivan's helpful taxonomy on rules and standards. "A legal directive is 'rule'-like when it binds a decisionmaker to respond in a determinate way to the presence of delimited triggering facts." 230 A rule seeks to encapsulate the essence of the animating principle of the legal directive but it displaces that principle inasmuch as it directs the decisionmaker to follow and apply the rule itself, not its animating principle. ${ }^{231}$ By contrast, "[a] legal directive is 'standard'-like when it tends to collapse decisionmaking back into the direct application of the background principle or policy to a

circumstances cruel and unusual punishment forbidden by the Eighth and Fourteenth Amendments, I would vacate respondent's death sentence ...." (citation omitted)).

227 Id. at 702.

228 See Kathleen M. Sullivan, The Supreme Court 1991 Term-Foreword: The Justices of Rules and Standards, 106 HARV. L. REV. 22, 57-58 (1992).

229 See id. at $58 \mathrm{n} .231$ ("[T] In fact, there is only a continuum of greater or lesser 'ruleness."').

${ }^{230}$ Id. at 58. See also Duncan Kennedy, Form and Substance in Private Law Adjudication, 89 HARV. L. REV. 1685, 1687-88 (1976) (describing the paradigmatic rule as one that "is a directive to an official that requires him to respond to the presence together of each of a list of easily distinguishable factual aspects of a situation by intervening in a determinate way").

231 See Sullivan, supra note 228, at 58 ("A rule captures the background principle or policy in a form that from then on operates independently."). 
fact situation." 232 Standards typically direct the decision-maker to take into account the totality of relevant circumstances rather than a small number of triggering facts. ${ }^{233}$

The two most salient consequences of articulating a legal directive as a rule, on the one hand, or a standard, on the other, are the amount of predictability afforded to actors ex ante and the amount of discretion permitted decision-makers ex post. ${ }^{234}$ That is to say, rules provide greater predictability to actors whose conduct is regulated by the directive regarding the legal consequences of their conduct, while standards provide those actors with far less predictability about those consequences. ${ }^{235}$ At the same time, rules afford less discretion to decisionmakers responsible for evaluating the conduct of those governed by the legal directive, while standards afford those decision-makers more discretion in evaluating whether the conduct satisfies those directives. ${ }^{236}$

The debate between Justices Black and Frankfurter over how to interpret the Due Process Clause of the Fourteenth Amendment was the paradigmatic debate between rules and standards. ${ }^{237}$ The "fundamental fairness" approach, focusing on the nebulous nature of the words "due process of law," was inherently standardbased. ${ }^{238}$ We saw this in the application of the Betts "special circumstances"

232 Id. See also Kennedy, supra note 230, at 1688 ("A standard refers directly to one of the substantive objectives of the legal order.").

233 See Sullivan, supra note 228, at 59. See also Kennedy, supra note 230, at 1688 ("The application of a standard requires the judge both to discover the facts of a particular situation and to assess them in terms of the purposes or social values embodied in the standard.").

234 See Kennedy, supra note 230, at 1688 ("[T] he two great social virtues of formally realizable rules, as opposed to standards or principles, are the restraint of official arbitrariness and certainty.").

${ }^{235}$ See Frederick Schauer, Justice Stevens and the Size of Constitutional Decisions, 27 RUTGERS L.J. 543, 556 (1996) (observing that "rule-based decisionmaking increases the likelihood of wrong results just because of its necessarily premature decision of cases that have not yet arisen" but that this comes "in exchange for the virtue[] of predictability"); see also Louis Kaplow, Rules Versus Standards: An Economic Analysis, 42 DuKE L.J. 557, 560 (1992) (adopting a definition of rules and standards by "which the only distinction between rules and standards is the extent to which efforts to give content to the law are undertaken before or after individuals act" (emphasis omitted)); Carol M. Rose, Crystals and Mud in Property Law, 40 Stan. L. Rev. 577, 592 (1988) ("Judicial punctiliousness about establishing and following clear rules, one would suppose, can influence behavior in the direction of greater productivity or carefulness.").

236 Sullivan, supra note 228 , at 57 ("[L]egal directives take different forms that vary in the relative discretion they afford the decisionmaker.").

237 See Alan K. Chen, The Ultimate Standard: Qualified Immunity in the Age of Constitutional Balancing Tests, 81 IowA L. REV. 261, 299 n.220 (1995) (noting the "rules-standards debate between Justices Frankfurter and Black [that] arose in the context of the incorporation debate"); Jeffrey L. Fisher, Categorical Requirements in Constitutional Criminal Procedure, 94 GEO. L.J. 1493, 1526 (2006) ("Justice Black championed rules, while Justice Frankfurter defended standards."); Sullivan, supra note 228, at 26 (characterizing the debate between Justices Black and Frankfurter as a debate over rules versus standards).

238 See Chhablani, supra note 150, at 44 ("[A]n ad hoc balancing of state and individual interests is more properly a feature of due process analysis."). 
standard, by which appointment of counsel was required in state criminal cases only in the presence of special circumstances describing a variety of factors relating to the characteristics of the defendant and the charges against him. And we saw it in the application of the "overborne will" standard, which took into account the totality of the circumstances characterizing a police interrogation and the suspect being interrogated. These tests left trial judges and police officers, respectively, up in the air over whether a constitutional violation would later be found because each test can be employed only after a trial or an interrogation, respectively, has already taken place.

This unpredictable, retrospective nature of the "fundamental fairness" approach is reflected in the very language of the Due Process Clause. ${ }^{239}$ The injunction that persons not be "deprived of life, liberty, or property without due process of law" is inherently retrospective. It can come into play only after the person has been convicted and thereby "deprived of life, liberty, or property." When the Supreme Court translated this edict into a requirement of "fundamental fairness," the retrospective nature of the inquiry was even clearer, given that "fairness is an ex post consideration.",240

The incorporation approach leans heavily on rules. The "meta-rule" of incorporation is to apply the Bill of Rights to the States exactly as it applies to the federal government. ${ }^{241}$ And to the extent that each purportedly incorporated provision is capable of rule-like application, incorporation favors rules over standards in that respect as well. ${ }^{242}$ We saw this in Gideon, with its bright-line rule that appointed counsel was required in every serious criminal case, and we saw it in Miranda, with its bright-line rule that confessions not preceded by warnings and waiver are deemed compelled. It is thus no coincidence that Justice Black rested his incorporationist approach in large part on the need to constrain the discretion of

239 See id. at 41 ("[A] retrospective evaluation ... . is a hallmark of Due Process analysis focused on the fundamental fairness of proceedings ....”).

240 Rose, supra note 235, at 593.

241 See Schauer, supra note 235, at 558 (discussing Justice "Black's rule-based approach . . . to questions of incorporation").

${ }^{242}$ Incorporation becomes less rule-like when the purportedly incorporated provision itself sets out a standard rather than a rule, such as, arguably, the Fourth Amendment's proscription of "unreasonable searches and seizures." U.S. CONST. amend. IV. But even here, the Court has attempted to structure rights in a rule-like way when possible. For example, the Court has interpreted the Fourth Amendment as erecting a "warrant-preference rule," instructing police to secure a warrant prior to searching and seizing, subject to a number of exceptions. See Katz v. United States, 389 U.S. 347, 357 (1967) (" $[S]$ earches conducted outside the judicial process, without prior approval by judge or magistrate, are per se unreasonable under the Fourth Amendment - subject only to a few specifically established and well-delineated exceptions.") (footnote omitted). And even within these exceptions, the Court has, with varying degrees of success, preferred to fashion bright-line rules to guide officer conduct. See, e.g., United States v. Robinson, 414 U.S. 218, 235 (1973) (establishing that the person of arrestee may be searched upon arrest with no additional showing of suspicion). 
judges in determining constitutional commands. ${ }^{243}$ And it is no surprise that Justice Scalia, his successor in carrying the banner of "total and exclusive" incorporation - the idea that the Fourteenth Amendment incorporates the Bill of Rights but provides no further protection ${ }^{244}$-is an outspoken advocate of judicial use of rules over standards whenever possible. ${ }^{245}$

Again, the temporal aspect of incorporation-its prospectivity and, thus, predictability - is reflected in the provisions that are now incorporated against the States. The Sixth Amendment, for example, lists the rights that must be provided before and during the trial itself: it must be public, before a jury, with the aid of counsel, attended by the rights of confrontation and compulsory process, and so forth. ${ }^{246}$ It consists of a series of imperatives to be followed before the fact, not a standard to evaluate conduct after the fact.

Thus, the shift from fundamental fairness to incorporation-from Betts to Gideon and from Brown to Miranda - can be seen as a shift from standards to rules. This movement encompassed two separate shifts correlating to two of the most important characteristics of rules and standards: from less to greater predictability for before-the-fact police (in interrogating) and judges (in appointing counsel); and from greater to less discretion for after-the-fact judges in determining whether the Constitution had been violated.

\section{B. Step Two: The Persistence of Standards}

Rules, however, rarely completely displace standards. Standards persist. ${ }^{247}$ For one thing, rules sometimes dispatch standards merely temporarily, only to have them pop up again in a different place in the analysis, to be battled once more, like a game of Whack-a-Mole. The rule created in Miranda falls into this category.

243 See supra note 28 and accompanying text. See also Schauer, supra note 235, at 558 (observing that Justice Black's position on incorporation was based on the "view that understanding the constitutional text in rule-like terms would produce less variable decisions in the hands of the Court itself").

244 See supra note 29 and accompanying text; see also Toni M. Massaro, Reviving Hugo Black? The Court's Jot for Jot Account of Substantive Due Process, 73 N.Y.U. L. ReV. 1086, 1090 \& n.13 (1998) (characterizing Justice Scalia as a "justice . . who likely would, if not for stare decisis, happily pitch substantive due process caselaw altogether”).

245 See generally Antonin Scalia, The Rule of Law as a Law of Rules, 56 U. CHI. L. REv. 1175 (1989); see also Schauer, supra note 235, at 558 (observing that Justices Black and Scalia were both "proponents of rules").

246 In all criminal prosecutions, the accused shall enjoy the right to a speedy and public trial, by an impartial jury of the State and district wherein the crime shall have been committed, which district shall have been previously ascertained by law, and to be informed of the nature and cause of the accusation; to be confronted with the witnesses against him; to have compulsory process for obtaining witnesses in his favor, and to have the Assistance of Counsel for his defense.

U.S. CONST. amend. VI.

247 See Rose, supra note 235, at 604 (describing how rules often give way to standards). 
Miranda's bright-line rule added, to the pre-existing right not to be coerced into making statements, the right to avoid introduction into evidence of statements made during custodial interrogation in ignorance of the rights to silence and counsel. Once the newly created right is satisfied, however, the pre-existing right to be free from coercion-measured by the same messy standard developed through common-law accretion since 1936 - takes center stage once more.

Moreover, creation of a rule might spawn new questions that can be answered only with reference to standards. Like the heads of the mythical Hydra, each standard that is slain might be replaced with one or more new standards. Gideon falls into this category. Almost as soon as the Court fashioned the bright-line Gideon rule that indigent defendants in state court were entitled to the assistance of appointed counsel in all cases, it was confronted with the question of what level that assistance of counsel had to meet in order to be constitutionally sufficient. But counsel must take countless actions and make countless decisions in the defense of a criminal case. Moreover, each individual action and decision cannot neatly be categorized as "right" or "wrong," but instead lies on a continuum of competence, as does the totality of counsel's performance. This explains why, when lower courts first began to tackle this issue in federal cases even prior to Gideon, they housed this inquiry in the Fifth Amendment's flexible Due Process Clause rather than the Sixth Amendment's more rigid Assistance of Counsel Clause. ${ }^{248}$ It also explains why critics of the Strickland standard have observed that it essentially, and incongruously, resurrects the old due process fundamental fairness paradigm in an incorporationist world. ${ }^{249}$ Measuring the competency of counsel, like determining whether an interrogation was coercive, is irreducibly standard-like.

\section{Step Three: Scaffolding Rules}

In short order, the Court eventually realized that the Gideon and Miranda rules could not stand on their own because they went only so far in delineating rights of defendants and suspects. Additional legal directives were necessary to buttress these rules. The Court needed to erect what legal historian Alan Watson has called "legal scaffolding," or legal directives to operationalize pre-existing directives. ${ }^{250}$ A bare totality-of-the-circumstance test for effectiveness of counsel might have sufficed, as might have resort to the old due process voluntariness test for coercion. But having already rejected nebulous standards in favor of brightline rules when it opted for incorporation, the Court was loathe to revert to messy,

248 See supra notes 150-152 and accompanying text.

249 See generally Chhablani, supra note 150.

250 See Alan Watson, Society and Legal Change 87 (2d ed. 2001) (defining "legal scaffolding" as "a back-up system . . . which is dictated by the need to modify the rather more basic rules"). 
fact-intensive standards, at least when it had the choice. Incorporation demanded scaffolds in the form of rules rather than standards if at all possible.

The strong Strickland and Miranda counter-presumptions fit this paradigm. Of course, a heavy but theoretically rebuttable presumption is not quite as rule-like as a conclusive presumption, by which a legal conclusion flows inevitably from a given fact, such as the Gideon and Miranda presumptions. ${ }^{251}$ But a strong presumption is nevertheless far more like a rule than it is like a standard. ${ }^{252}$ This becomes particularly clear when we measure the effects of the counterpresumptions using the same metrics we used to evaluate the rule-ness of Gideon and Miranda themselves: discretion afforded ex post and predictability provided ex ante.

Both the presumption of attorney competence and the presumption of noncoercion sharply curtail judicial discretion. The former requires decision-makers evaluating claims of incompetent counsel to give every benefit of every doubt to counsel and to rationalize counsel's decisions, if at all possible, as strategy. Only when counsel's actions defy rationalization as strategy will a court later find counsel's performance to have been deficient. Judges are thus forbidden from delving too deeply into the actual motivations for counsel's decisions. Instead, the presumption of attorney competence tells reviewing judges to take only a superficial first pass at counsel's actions in search of a rational basis for her decisions. Only in the rare case that such a rational basis is not apparent does the reviewing judge have discretion to probe more deeply. Unless counsel's actions appear on their face to be so outrageous as to be beyond rational explanation, the record need not be scrutinized further to determine whether they were truly strategic.

Likewise, the presumption of non-coercion demands a constrained and superficial role for judges reviewing whether a confession has been coerced. Gone are the days when judges were expected to discern the dozens of factors that might have made an interrogation coercive, evaluate how these factors interacted with one another, and reach a refined conclusion as to whether the suspect's will had been overborne. Instead, judges are confined almost exclusively to looking at whether Miranda warnings were given and waived. Only in the rare case where some circumstance of the interrogation or characteristic of the suspect raises a red flag - some aspect that appears on its face to be truly outrageous - may judges

251 The Gideon and Miranda conclusive presumptions - respectively, that the presence of criminal charges is always a "special circumstance" and that custodial interrogation is inherently compulsive - brings to mind Professor Sullivan's evocative characterization of a rule "as simply the crystalline precipitate of prior fluid balancing that has repeatedly come out the same way." Sullivan, supra note 228 , at 62 .

${ }^{252}$ See id. at 60 n.246 ("[S]trong presumptions . . . tend toward the rule-like pole of the continuum."); Kathleen M. Sullivan, The Jurisprudence of the Rehnquist Court, 22 NovA L. REV. 743, 752 (1998) ("Almost as rule-like in practice [as categorical tests] are tests that use strong presumptions to decide cases once a threshold classification has been made."). 
probe more deeply. In mine-run cases of intensive interrogation, even those that might have been deemed coercive in an earlier day, the presumption of noncoercion holds and the judicial role is strictly cabined.

In terms of predictability, the Miranda and Strickland counter-presumptions are strongly rule-like as well. Gone are the days when police could scarcely know during the course of a lengthy interrogation what factors a court would later find significant-including those unknown and unknowable to the officer-in determining whether the interrogation was coercive. Predictability under such a regime was at its nadir, which is precisely why the Court decided in Miranda that it needed to "give concrete constitutional guidelines for law enforcement agencies and courts to follow." 253 Today, the presumption of non-coercion acts as a safeharbor rule, telling police in advance that, as long as they adhere to the dictates of Miranda, their tactics later in the interrogation will virtually never be questioned.

The presumption of attorney competence, too, acts as a safe-harbor rule of sorts, telling defense attorneys that they are free to defend their clients in the manner in which they choose and their tactics will virtually never be secondguessed. While the guidance so provided does not consist of concrete steps to be followed, it is no less clear in its message: "Do as you wish and you will (almost) never be questioned." The presumption of attorney competence provides predictability for defense counsel by laying out wide parameters within which to do their jobs, ensuring that their actions will almost always be ratified later.

That incorporation strongly prefers rules to standards does not necessarily explain why the Court chose these rules. But the Miranda presumption of noncoercion was all but inevitable. To understand why, one must remember that the Supreme Court has never resolved the question of what constitutes coercion in violation of due process principles. Instead, the Court pulled something of a baitand-switch in Miranda, changing the focus from coercion to compulsion, two concepts that are not synonymous. ${ }^{254}$ Even if the Miranda Court equated custodial interrogation without administration of warnings with compulsion, it dodged the question of coercion. True, a later Court might have concluded that all custodial interrogation, whether warned or not, constitutes compulsion, thereby creating a rule that would have obviated the need for any further refinement of the coercion question. But such a rule would have been a sharp deviation from, not an implementation of, Miranda. Thus, absent the rule-like presumption of noncoercion, courts and police would have been thrown back into the pre-Miranda due process morass.

253 Miranda v. Arizona, 384 U.S. 436, 441-42 (1966).

254 See Stinneford, supra note 209, at 465-66 (observing that the Miranda Court "explicitly denied that the two terms mean the same thing, holding that a confession obtained through custodial interrogation could violate the Fifth Amendment even if it would be considered voluntary under the Due Process Clause"). 
It is also difficult to imagine any other rule-like guidelines that the Court could have created in Strickland other than something akin to the presumption of attorney competence. Numerous critics of the approach adopted in Strickland, including Justice Marshall in dissent in that case ${ }^{255}$ have suggested adoption, in whole or in part, of the American Bar Association's Standards for Criminal Justice, Defense Function ("ABA Standards") ${ }^{256}$ to give concrete guidance for attorneys and reviewing judges. ${ }^{257}$ But for the Court to have adopted all or part of the ABA Standards as a constitutional requirement would have been highly problematic.

For one thing, the very first standard cautions that "the[] standards . . are not intended to be used as criteria for the judicial evaluation of alleged misconduct of defense counsel to determine the validity of a conviction." 258 Moreover, many of the standards instruct defense counsel how to conduct themselves when faced with ethical dilemmas having little or nothing to do with competent representation. ${ }^{259}$ For example, Standard 4-4.6 addresses the thorny issue of what defense counsel should do after coming into possession of physical evidence that implicates a client in criminal activity. ${ }^{260}$

But more fundamentally, the ABA Standards provide . . . well, standards. Accordingly, the Standards consist of general guidelines, shot through with imprecise and context-dependent language. For example, in expounding upon one of the most important and most litigated duties of counsel, the duty to investigate, Standard 4-4.1 tells us that counsel must "explore all avenues leading to facts

\footnotetext{
255 See Strickland v. Washington, 466 U.S. 668, 709 \& n.3 (1984) (citing with approval various attempts by lower courts "to develop particularized standards designed to ensure that all defendants receive effective legal assistance" and noting that "[m]any of these decisions rely heavily on the standards developed by the American Bar Association").

256 ABA Standards for Criminal Justice: Prosecution and Defense Function (3d ed. 1993) [hereinafter ABA STANDARDS].

257 See, e.g., William H. Erickson, Standards of Competency for Defense Counsel in a Criminal Case, 17 AM. CRIM. L. Rev. 233, 243 (1979) ("recommend[ing] increased reliance on the" ABA Standards). See also Richard L. Gabriel, Comment, The Strickland Standard for Claims of Ineffective Assistance of Counsel: Emasculating the Sixth Amendment in the Guise of Due Process, 134 U. PA. L. REV. 1259, 1283 n.144 (1986) ("Those who support the categorical approach generally contend that the American Bar Association Standards for the Defense Function provide appropriate rules.").

258 ABA STANDARDS, supra note 256, Standard 4-1.1; see William J. Genego, The Future of Effective Assistance of Counsel: Performance Standards and Competent Representation, 22 Ам. CRIM. L. REv. 181, 205 (1984) (making similar observations).

259 See Calhoun, supra note 170, at 437-38 ("[S]ome of the American Bar Association's standards for defense attorneys are inappropriate because they concern defense counsel's ethical conduct and general role in the criminal justice system without referring specifically to the attorney's responsibility to provide the defendant with effective assistance of counsel.") (footnote omitted); Erickson, supra note 257, at 244 ("A number of the standards express self-evident concepts of professional ethics which, at most, serve to aid a lawyer in resolving some of the conflicting demands placed upon him by his clients and his responsibility to the court.") (footnote omitted).

260 See ABA STANDARDS, supra note 256, Standard 4-4.6.
} 
relevant to the merits of the case."261 But they do not tell us how far down every "avenue[]" counsel must travel, nor how much deference to accord counsel in her determination that some facts are not "relevant" to the case. Other examples abound of imprecision in the Standards. Counsel must consult with her client about strategic decisions only "where feasible and appropriate." 262 Counsel must provide her client with information only to the extent that requests therefor are "reasonable."263 Counsel may not recommend acceptance of a plea until after "appropriate investigation and study of the case." ${ }^{264}$ These general guidelines are non-controversial, as one might expect from directives that one's conduct be "appropriate" and "reasonable." But for that very reason they tell us almost nothing about how defense counsel should conduct themselves in specific cases. It is unsurprising that even Professor Vivian Berger, an early and prominent critic of Strickland, dismissed the ABA Standards as being "vague to the point of uselessness" in assessing specific arguable missteps by counsel. ${ }^{265}$

Moreover, judicial and academic attempts to supplement and amplify these standards through a "checklist" approach have not led to more concrete rules but only equally general standards. For example, Judge William Erickson, in his influential pre-Strickland piece, distilled several basic duties from the ABA Standards, including that defense counsel "must diligently and actively participate in the full and effective preparation of his client's case," must "investigate carefully all defenses of fact and of law that may be available," and "must confer with his client without undue delay and as often as necessary to elicit matters pertinent to his defense." 266 But imposing upon counsel a duty to act "diligently" and "actively," to prepare "full[y] and effective[ly]," to "investigate carefully," and to confer "without undue delay and as often as necessary" does little more than does a general edict that counsel act "reasonably." Similarly, in another influential pre-Strickland piece, Judge David Bazelon endorsed an approach that required counsel, among other things, to "[c]onfer with the client . . . as often as necessary," "develop all appropriate defenses," and "[c]onduct all necessary investigations." But hedging obligations with words such as "necessary" and "appropriate" hardly creates sharp-edged rules. Rather, these are just different ways of re-stating a vague standard of "reasonably effective assistance." Likewise, it is one thing to suggest that defense counsel "must make ... an opening statement," "objections

261 Id., Standard 4-4.1.

262 Id., Standard 4-5.2(b).

263 Id., Standard 4-3.8(a).

264 Id., Standard 4-6.1.

265 Berger, supra note 135, at 83; see also Genego, supra note 258, at 204 ("When addressing what a lawyer must do, the Standards issue only broad, generalized commands . . ."); Peter W. Tague, The Attempt to Improve Criminal Defense Representation, 15 AM. CRIM. L. REV. 109, 131 (1977) ("[T]he [ABA] guidelines offer little help in answering specific questions.").

266 Erickson, supra note 257, at 245 (citing People v. Pope, 590 P.2d 859, 866-67 (1979)).

267 David L. Bazelon, The Defective Assistance of Counsel, 42 U. Cin. L. Rev. 1, 31 (1973) (citing Coles v. Peyton, 389 F.2d 224, 226 (4th Cir. 1968)). 
that further the defendant's interests," and "a closing argument that does not hurt the defendant's case," must call witnesses that counsel "reasonably believes will help the defendant's case," and must impeach all prosecution witnesses unless counsel "reasonably believes that to do so . . . would do more harm than good." 268 It is quite another to apply these edicts to an actual case where the issue might be whether the opening statement was fulsome enough to give the jury a good preview of the defendant's narrative, or whether declining to make a valid objection or really "go after" a prosecution witness for fear of antagonizing the jury was a reasonable strategy, or whether the benefits outweighed the costs of putting a particular witness on the stand, or whether a closing argument that depicted the defendant as deeply immoral but not criminal "hurt the defendant's case."

Thus, the choice in Strickland was not between different sets of rules. It was between rules and standards: the heavily rule-like presumption of attorney competence and the morass of case-by-case adjudication based solely on the nebulous standard of "reasonably effective assistance." Having largely escaped from this snare twenty years earlier, the Court was loath to return.

\section{CONCLUSION}

This Article is neither an indictment nor a celebration of the Court's current Gideon and Miranda jurisprudence. It is one explanation, among others, for how we arrived here. More than that, however, it is an attempt to flush out the darker side of incorporation. Methodologically, incorporation carries a great many benefits vis-à-vis the other main competing approach, "fundamental fairness" analysis, primarily predictability and constraint on judicial discretion. And in preincorporation days, lack of predictability and unconstrained judicial discretion all too often operated to the detriment of criminal defendants. But those who favor incorporation over "fundamental fairness" should recognize that with the sweet comes the bitter, even if incorporation was the sweeter choice overall.

268 Calhoun, supra note 170, at 439. 